\title{
Retraction by corruption: the 2012 Séralini paper
}

\section{Eva Novotny"}

Clare Hall, Herschel Road, Cambridge, CB3 9AL, United Kingdom

On 19 September 2012 a paper written by the group led by G.-E. Séralini was published online and then in print in the November 2012 issue of Food and Chemical Toxicology. The study reported in the paper examined the effects on the health of rats of a genetically engineered maize, Monsanto's NK603, and of the herbicide Roundup the maize is designed to tolerate. The paper elicited severe criticism from individual scientists and organizations, including some regulators and learned societies. Critical Letters to the Editor resulted in the retraction of the paper by the Editor-in-Chief of the journal, not on any scientific grounds but solely because the study was "inconclusive". Proponents of genetic engineering claim, wrongly, that there is now a consensus that genetically modified crops are safe to consume. To maintain that stance, it is necessary to destroy the credibility of any scientific evidence to the contrary and also the reputations of the researchers who obtained such evidence. In some cases even the institutions where the work was carried out and the journals publishing the results are attacked. Monsanto Company, in particular, has a huge financial stake in genetically modified crops and Roundup. Conflicts of interest of individuals, corporations and regulators have in the past triumphed over scientific evidence of harm. Private documents from the company, released by a law court in August 2017, reveal covert manoeuvring by Monsanto to have the Séralini et al. paper retracted, in which the then Editor-in-Chief of the journal colluded. To this day the earlier, demonstrably flawed, research by Monsanto scientists finding NK603 to be "safe and nutritious" remains in print in the same journal. Meanwhile, the serious implications for public health have been disregarded by Monsanto, the critics and the regulators. Unfortunately, the "Séralini affair" is not unique.

Keywords: EFSA, Monsanto, regulation, tumours

\section{INTRODUCTION}

It is often claimed that there is now a "general consensus" that genetically modified ${ }^{1}$ foods are safe for consumption. Yet this is manifestly untrue, as evidenced by a publication entitled "Statement: No scientific consensus on GMO safety", signed by some 300 scientists and other experts [1] independent of the GM industry.

The dichotomy between GM proponents and GM critics exemplifies the conclusions of Kvakkestad et al. [2], who interviewed 62 scientists from universities or industry working in the fields of molecular biology, ecology and conventional plant breeding. Of these, $92 \%$ could be classified into one of two groups: one with a moderately negative attitude and the other with a positive attitude toward GM crops. The second group contained no ecologists but all of the scientists working in the GM industry. Another study by Diels et al. [3] examined 94 articles and found that a favourable opinion about a GM crop was associated with a professional conflict of interest. Data on financial conflicts of interest was scarce, as funding was in many cases undeclared, although articles that did not declare funding tended to be associated with a favourable outcome.

The claim of consensus is widely made in an apparent effort to persuade the public and discredit the scientists who refute it with scientific evidence. In order to silence such scientists, various methods have been employed, such as defamation of a researcher's competence, ad hominem attacks and even physical threats. In the past, Árpád Pusztai [4] and Ignacio Chapela [5] have been notable victims of a covert campaign to achieve retraction, on spurious grounds, of results unfavourable to the GM industry. The retraction of the Séralini et al. (2012) paper [6] is especially irrational because the work, which found harm from a GM maize in a laboratory feeding trial, was essentially a superior

\footnotetext{
*E-mail: en@en.eclipse.co.uk

${ }^{1}$ The following standard abbreviations will be used throughout this paper: GM, genetically modified; GE, genetically engineered (meaning the same as GM); GMO, genetically modified organism. A distinction might be made between genetic engineering, implying change in a genome accomplished by human manipulation of a genome rather than by a natural process, and genetic modification, which can include genetic engineering and also alteration of a genome by natural processes in the wild or by traditional breeding. In this paper, the terms will be regarded, as usual nowadays, to be synonymous.
} 
repetition of an older study [7] by Monsanto, the developer of the maize, that had found no harm; that paper had been published in the same journal and remains in print.

Much has been written about the "Séralini affair": including a discussion of the experiment and its repercussions in a book by Fagan, Antoniou and Robinson [8]; in a paper by Fagan, Traavik and Bøhn [9] describing the experiment and placing it in the context of the growing practice of retraction followed by republication; in a paper by Resnick [10] with the purpose of drawing lessons for journal editors; and in articles summarizing the Séralini paper and its aftermath by Engdahl [11] and Novotny [12]. The present paper brings together the evidence of widespread corruption among individuals, organizations and regulators, resulting from interests associated with the GM industry, and which led to the retraction, together with new developments that corroborate the validity of the Séralini et al. study.

An important consequence of this corruption of science is that crops that have gained regulatory approval as "safe" are harming the health of farm animals and, very probably, humans.

\section{THE MONSANTO 2004 PAPER}

\subsection{Design of the experiment}

In 2004, Monsanto scientists led by Hammond [7] published a 13-week study on the feeding of Monsanto's GM maize NK 603 to Sprague Dawley rats. The design of the experiment was adapted from guideline 408 of the Organization for Economic Cooperation and Development (OECD). A total of 400 rats, aged approximately 6 weeks, was divided into 10 groups of male rats and 10 groups of female rats, with 20 animals per group. Each diet was given to one male group and one female group. The diets were: (1) a test diet with 33\% (by weight) of NK603 maize, (2) a test diet with $11 \%$ of NK603, (3) a control diet with $33 \%$ of a "genetic representative" of NK603 but without the transgene, (4) a control diet with $11 \%$ of the genetic representative of NK603 without the transgene, (5)-(10) "reference diets" with $33 \%$ of various maizes "representing a variety of germ plasm". Diets containing $11 \%$ of either NK603 or the non-transgenic representative were supplemented with $22 \%$ of a commercial maize (Purina TestDiets) to bring all diets to the same level of maize content. Maize in groups 1-4 was grown at field test sites in Ohio during 1999, while the reference maizes were grown in Ohio and three other states of the USA during 1999. Maize in groups 1 and 2 was treated with Roundup herbicide during growing.
The grains used for the diets were analysed for nutrient components, pesticide residues (including glyphosate) and mycotoxins. The identity of NK603 was confirmed by polymerase chain reaction (PCR) analysis. The control and reference grains tested negative for NK603. Further discussion of the diets will follow in §14.1.

Blood samples were collected from 10 animals per sex per group after week 4 and also just prior to final sacrifice, "when possible" from the same 10 animals. Urine was collected from the same animals.

At the end of 13 weeks, all animals were anaesthetised and sacrificed, and organs and tissues were collected. The high-dose test groups were compared with the highdose control group and the mean of the reference groups, while the low-dose test groups were compared with the low-dose control group. The statistical analysis for each sex used ANOVA and "specific treatment combinations were compared by means described in the paper".

\subsection{Results}

One male rat receiving the $33 \%$ NK603 diet died on day 82 of the study. The cause of death could not be determined and was deemed to be unrelated to consumption of the GM maize.

"A few statistically significant differences in weekto-week weight gain were observed, particularly in males, but these differences within the mean \pm 2 standard deviations of the population of reference controls appeared randomly among the groups and were either not doserelated or not consistently observed throughout the study. They were not considered to be test article-related.

"Food consumption was generally similar between test, control and reference control groups.

"Clinical pathology parameters were generally comparable for all groups. There were a few statistically significant differences between the Roundup Ready [NK603] groups and the control groups after 4 weeks and at study termination (urinalysis). These differences were not considered to be test article-related since they were within the mean \pm 2 standard deviations of the population of reference controls, were different from one control group but not the other, were sometimes not doserelated (observed at the low dose but not the high dose), and/or occurred after 4 weeks but not at study termination.

"There were no biologically meaningful differences in hematology results.

"There were no biologically meaningful differences in serum chemistry results.

"There were no statistically significant differences. ${ }^{2}$

\footnotetext{
${ }^{2}$ Stated for all four tables showing the results for haematology and serum chemistry.
} 
"This study complements extensive agronomic, compositional and farm animal feeding studies with Roundup Ready corn grain, confirming it is as safe and nutritious as existing commercial corn hybrids."

\subsection{Problems}

\section{(1) Short duration of study}

The feeding trial terminated at 13 weeks or 90 days, the typical duration of studies performed by the GM industry. As will be seen below from the Séralini et al. paper, it was at about 100 days that the minor differences between treated animals and controls began to be major.

\section{(2) Extraneous control groups}

For scientific accuracy, there should have been only one control group for each sex. The control groups (one for males, one for females) at $33 \%$, containing only the non-transgenic representative maize, are the only valid control groups. Use of reference controls serves only to blur the statistical results by widening the permissible ranges of the parameters being tested when a diversity of maize varieties is grown under a range of conditions of soil and weather. In addition, the diets of the $11 \%$ groups contained $22 \%$ of commercial maize of unknown provenance, again expanding the range of parameters (see Table 1). Use of the "reference controls" thus makes the entries for the treated animals appear more normal.

Table 1. Examples of widening of parameter ranges by extraneous control groups.

(a) (From Monsanto's Table 2) Haematology mean values \pm S.D.: male rats at end of study.

\begin{tabular}{ccccc}
\hline $\begin{array}{c}33 \% \\
\text { Control }\end{array}$ & $\begin{array}{c}11 \% \\
\text { Control }\end{array}$ & $\begin{array}{c}\text { Reference } \\
\text { Controls* }\end{array}$ & $\begin{array}{c}33 \% \\
\text { NK603 }\end{array}$ & $\begin{array}{c}11 \% \\
\text { NK603 }\end{array}$ \\
\hline $7.82 \pm 2.15$ & $9.81 \pm 2.05$ & $8.92 \pm 5.00$ & $9.27 \pm 2.57$ & $8.81 \pm 3.02$ \\
$5.82 \pm 1.60$ & $7.82 \pm 1.85$ & $6.95 \pm 4.48$ & $7.49 \pm 2.25$ & $6.92 \pm 2.79$ \\
\hline
\end{tabular}

(b) (From Monsanto's Table 5) Serum chemistry mean values \pm S.D.: female rats at end of study.

\begin{tabular}{ccccc}
\hline $\begin{array}{c}33 \% \\
\text { Control }\end{array}$ & $\begin{array}{c}11 \% \\
\text { Control }\end{array}$ & $\begin{array}{c}\text { Reference } \\
\text { Controls* }\end{array}$ & $\begin{array}{c}33 \% \\
\text { NK603 }\end{array}$ & $\begin{array}{c}11 \% \\
\text { NK603 }\end{array}$ \\
\hline $41 \pm 10$ & $41 \pm 8$ & $47 \pm 26$ & $48 \pm 13$ & $53 \pm 13$ \\
$118 \pm 96$ & $127 \pm 82$ & $103 \pm 102$ & $81 \pm 10$ & $143 \pm 158$ \\
$0.30 \pm 0.48$ & $0.40 \pm 0.70$ & $57 \pm 150$ & $0.50 \pm 0.85$ & $0.20 \pm 0.42$ \\
$7.60 \pm 0.45$ & $7.82 \pm 0.59$ & $7.55 \pm 1.00$ & $7.37 \pm 0.34$ & $7.42 \pm 0.68$ \\
$5.23 \pm 0.45$ & $5.60 \pm 0.58$ & $5.34 \pm 0.86$ & $5.09 \pm 0.41$ & $5.13 \pm 0.64$ \\
$2.26 \pm 0.40$ & $2.56 \pm 0.44$ & $2.47 \pm 0.66$ & $2.27 \pm 0.40$ & $2.26 \pm 0.32$ \\
$8.88 \pm 1.09$ & $9.15 \pm 1.16$ & $9.50 \pm 2.80$ & $9.54 \pm 0.93$ & $9.52 \pm 1.46$ \\
$7.30 \pm 0.49$ & $7.32 \pm 0.84$ & $7.65 \pm 1.92$ & $8.22 \pm 0.58$ & $7.69 \pm 0.69$ \\
\hline
\end{tabular}

*Mean \pm 2 S.D.
(3) Selection of 10 out of 20 rats

Blood and urine samples were taken from only 10 of the 20 animals in each group. No indication is given about how the selection was made. Although this can lead to distorted results depending on the manner of selection, the practice is permissible under OECD rules [66].

(4) Dismissal of statistically significant differences

The finding of statistically significant differences between treated groups and controls was mentioned for weight gain and clinical pathology parameters, but dismissed as "not considered to be test article-related". These differences should rather have served as warnings.

(5) Dismissal of nonlinear responses

Nonlinear responses are typical of endocrine disruption, but the authors accepted only monotonically increasing responses as valid.

(6) Dismissal of rat death

One rat died but "no apparent cause of death was found at necropsy". Again, this event was not considered to be test article-related. The death occurred at 82 days; the first rat died in the Séralini et al. study at 110 days while consuming the same maize. ${ }^{3}$

(7) Contaminated feed

Purina chow of the type used in the experiment was later found to be contaminated with glyphosate and GMOs, almost certainly resulting in the presence of contaminating GMOs in all the diets [13] (see §14.1).

\section{THE SERALINI ET AL. 2012 PAPER}

\subsection{Design of the experiment}

Disturbing health signs had been found in the Monsanto 2004 study, but they had been dismissed in the published paper. The Séralini work followed guideline 408 of the OECD but explored more parameters, and more frequently, than recommended. At the time, no guideline specifically designed for this type of experiment was available. All the maize used in the experiment, for both treated and control diets, was grown under similar conditions, in the same location, and spaced to avoid cross-contamination. ${ }^{4}$ An important feature of the study, not present in the Monsanto one, was the testing of Roundup, the glyphosate-based herbicide to which NK603 maize is designed to be tolerant. ${ }^{5}$

One field growing the GM maize was treated with Roundup and the other GM maize field and the non-GM

\footnotetext{
${ }^{3}$ Typical lifespan of Sprague Dawley rats is 2.5-3.5 years.

${ }^{4}$ Acquisition of the GM seeds was difficult as Monsanto, like other seed developers [14, 15], has a policy of not permitting its seeds to be used for research unless the investigator signs an agreement giving the company the power to prohibit publication of the results of the research. It required a year for Séralini to obtain the seeds for this feeding trial.

${ }^{5}$ Note that although regulatory agencies have tested glyphosate for safety, Roundup contains adjuvants making it several orders of magnitude more toxic than glyphosate alone [16, 17].
} 
field were not treated with the herbicide. These three fields of maize were used to create rat chow based on the standard diet A04 (Safe, France). The diets were analysed for the presence of NK603, and also for the possible presence of contaminants, as will be described in more detail in $\S 14.1$. A total of 200 rats, 5 weeks of age, was divided into 10 paired groups (male and female) of 10 animals per group, consuming diets as follows: Groups 1-3 had a test diet of NK603 grown with Roundup, at concentrations of $33 \%, 22 \%$ and $11 \%$, respectively; Groups 4-6 had a test diet of NK603 grown without Roundup, at concentrations of 33\%, 22\% and $11 \%$, respectively; Groups 7-9 had a test diet with the nearest isogenic non-transgenic maize at a concentration of $33 \%$ and with Roundup added to drinking water at the respective concentrations of $1.1 \times 10^{-80} \%(0.1 \mathrm{ppb}$ or $50 \mathrm{ng} / \mathrm{L}$ of glyphosate) (the level found in some tap waters), $0.09 \%$ (the U.S. Maximum Residue Limit of glyphosate in some GM animal feed), and $0.5 \%$ (half of the minimal agricultural working dilution); and Group 10 had a control diet containing the nearest isogenic nontransgenic maize at a concentration of $33 \%$. Diets containing less than $33 \%$ of NK603 contained enough of the nearest isogenic non-transgenic maize to bring the total maize content to $33 \%$.

Blood and urine samples were collected from each rat pretreatment, then monthly for the first 3 months and then at 3-month intervals throughout the lifetime of each rat. For animals living until the end of the study, there were 11 measurements in total.

Some animals had to be sacrificed prior to the end of the experiment on ethical grounds to end suffering, with some having developed huge tumours. All those remaining at the end of 720 days were also sacrificed. In all cases, organs and tumours were collected.

In the statistical analysis, "Biochemical data were treated by multivariate analysis with the SIMCA P(V12) software (UMETRICS AB, Umeå, Sweden)". Chemometrics tools included principal component analysis (PCA), partial least-squares to latent structures (PLS) and orthogonal PLS (OPLS).

Several differences from the Monsanto study should be noted (cf. §2.3): (1) the experiment extended (720 days) over most of the lifespan of the rats, ${ }^{3}$ not merely 90 days; (2) only one control group was used, containing $33 \%$ of the nearest isogenic, nontransgenic maize; there were no "reference controls" of animals fed irrelevant varieties of maize; (3) all the rats in each group were measured: none were selected out; (4) there was no dismissal of statistically significant differences; (5) nonmonotonic responses were accepted as real and attributed to effects of endocrine hormone disruption;
(6) the diet was carefully analysed and was not contaminated: in particular, and most importantly, it was free from other GM crops.

\subsection{Results}

\subsubsection{Main findings}

All results were found to be hormone- and sexdependent. The most dramatic, and unexpected, effect of consuming either NK603 or Roundup, or both, was the formation of tumours, especially mammary tumours, in females. In most of the treated groups, there was usually higher mortality and at earlier epochs, especially in females, in comparison with the control groups. Tumour formation and mortality will be described in more detail below. In treated females, the pituitary gland was the next most-affected organ after the mammary gland. In treated males, the liver notably suffered damage, together with the hepatodigestive tract and kidneys. The biochemical analysis found "very significant kidney chronic deficiencies" in treated animals, which could result from the endocrinedisrupting effects of Roundup and also from overexpression of the transgene. In females, the serum ratio of androgen to oestrogen was altered by both the GM maize and Roundup. In males, oestrogen levels were more than doubled at the highest dose of Roundup.

\subsubsection{Data on mortality and tumours}

In Figs 1 and 2, the panels are labeled "GMO" for tests on the GM maize grown without the herbicide, "R" for tests of Roundup in drinking water and the same diet as given to the controls, and "GMO+R" for tests on the GM maize grown with Roundup. Each panel shows the results for the three dosages, with solid lines of increasing heaviness for the increasing doses, and dashed lines for the controls. As there is only a single male control group and a single female control group, the same curve for control males or control females appears in each of the three panels for a given sex.

Deaths beyond the mean lifespan of controls, indicated by the vertical line in the grey area of Fig. 1, were considered to be largely due to aging. The mean lifespan for male controls was $624 \pm 21$ days and for females was $701 \pm 20$ days.

Among control females, one rat died near 550 days and a second died near 650 days. Among treated females, deaths began as early as about 300 days. At any time, the number of dead treated females was typically 2-3 times higher than for the controls. Large mammary tumours were the principal, or only, cause of death in all female groups. 

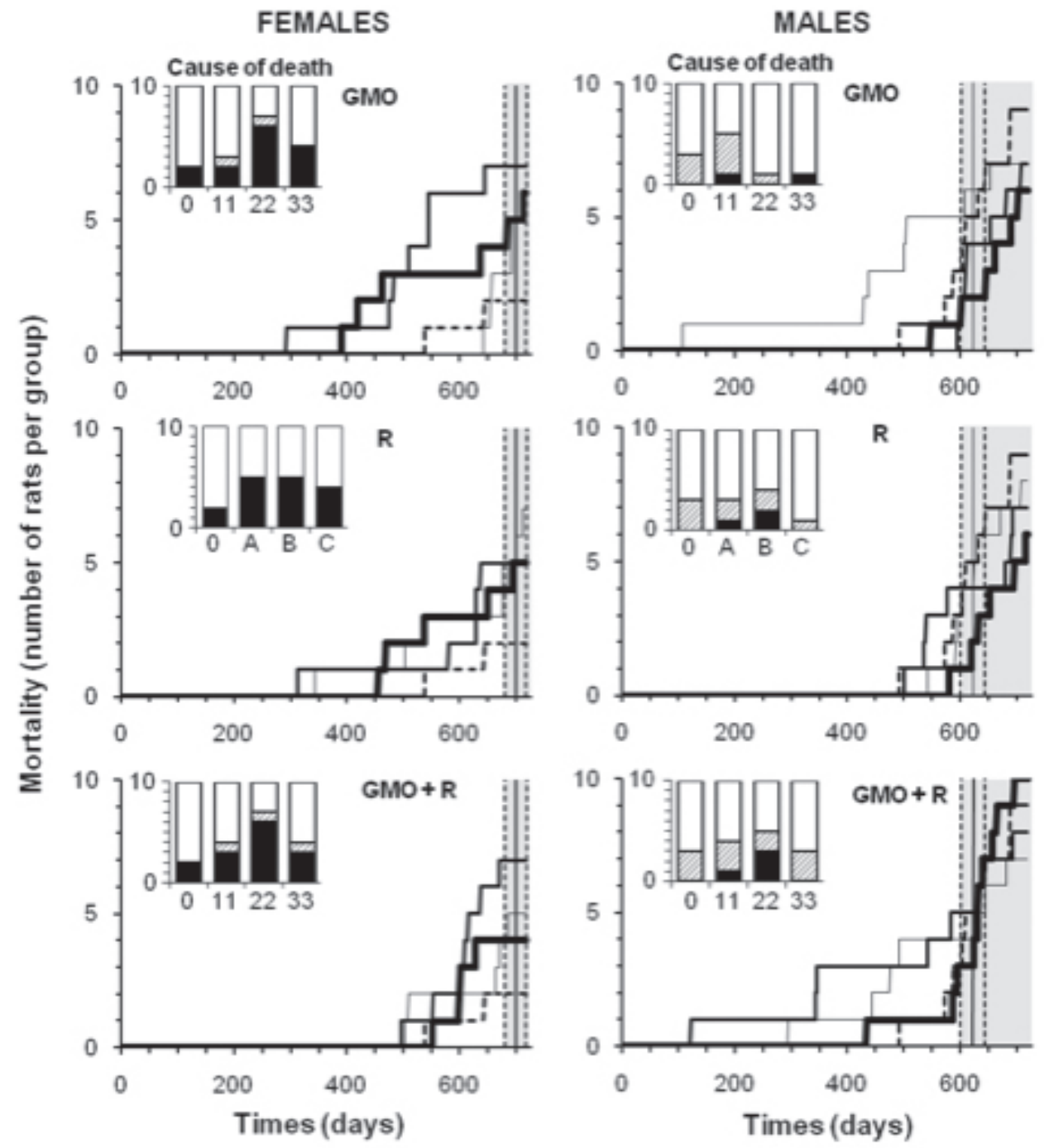

Figure 1. Mortality of rats fed with NK603 GM maize (GMO) treated or not with Roundup (R), and effects of Roundup alone [107]. GMO doses were 11, 22 and 33\% in the diet (thin, medium and bold lines, respectively) compared to the "substantially equivalent" closest isogenic non-GM maize (control, dashed line). Roundup was administrated in drinking water at 3 increasing doses: environmental (A), maximum residue limit allowed by law (MRL) (B) and half of minimal agricultural levels (C) (thin, medium and bold lines, respectively); the control was zero. Mean lifespan during the experiment for the control group is represented by the vertical line \pm SEM (dashed lines) and shaded grey to the limit of the graph on the right. Insets (bar histograms) show causes of mortality before mean control limit of life: black, euthanized to avoid suffering (tumours over $25 \%$ body weight, more than $25 \%$ weight loss, haemorrhagic bleeding, etc.); grey, spontaneous mortality; white, survived.

For male rats, the earliest death among controls occurred near 500 days, while for males in either the $\mathrm{GMO}$ or $\mathrm{GMO}+\mathrm{R}$ groups, the earliest death occurred in the vicinity of 100 days. In the $\mathrm{R}$ groups, the earliest death among treated animals occurred at the same time as in the control group, while the highest dose produced the lowest mortality. The nonmonotonic response to dose is explained as being due to disruption of endocrine hormones by Roundup: endocrine disruptors typically produce greater effects at low doses than at higher doses. The principal cause of death in males was "severe hepatorenal insufficiencies".

Fig. 2 summarizes the results for nonregressive palpable tumours. For females, a $2-3$-fold increase is seen at most times in the incidence of large, nonregressive palpable tumours for most treated animals in comparison with controls. Such a result was also found for the same strain of rats in a previous study [18]; and there is a threefold increase in comparison with the largest study [19] of the same strain of female rats. In the male control group, only a single animal developed these tumours, and that occurred in the last days of the experiment.

The paper passed peer review and was published online in Food and Chemical Toxicology (FCT) on 19 September 2012. It appeared in print in November 2012. 
FEMALES

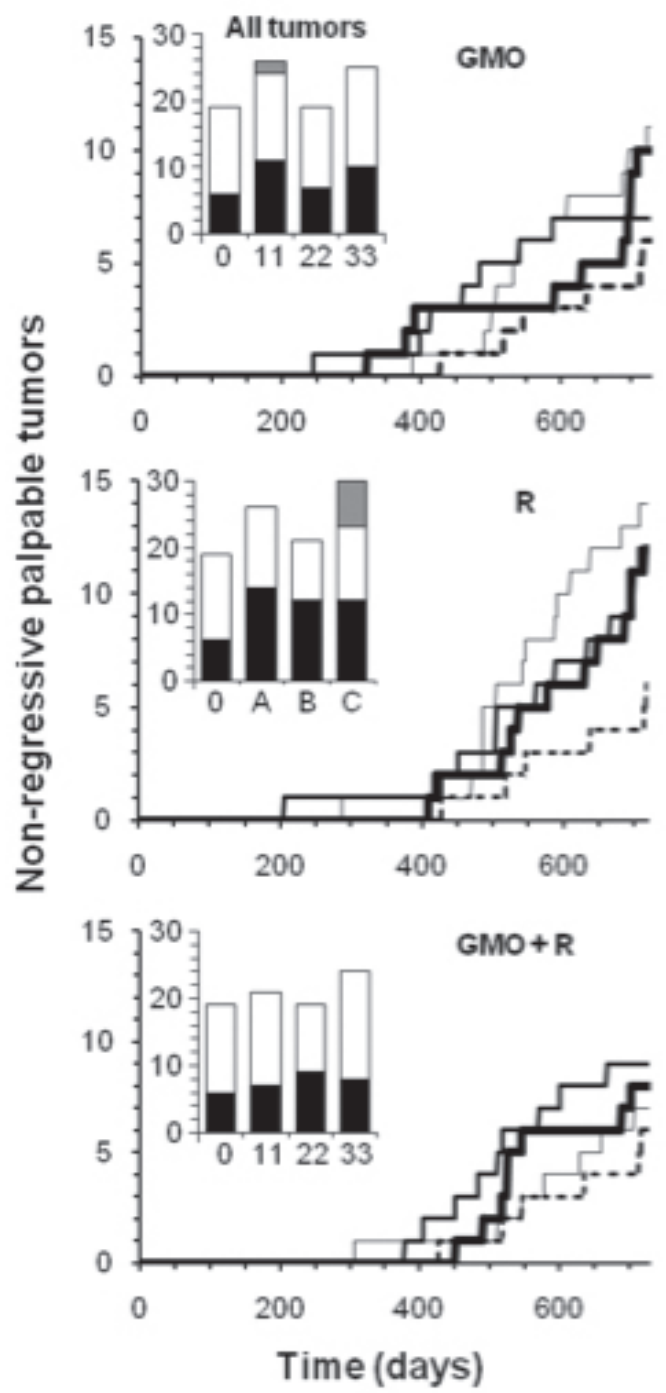

MALES

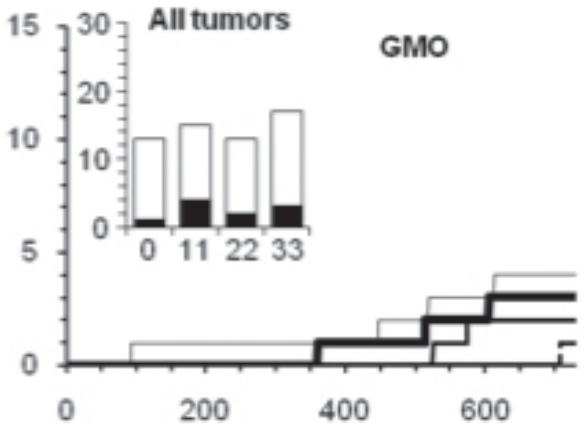

$\mathbf{R}$
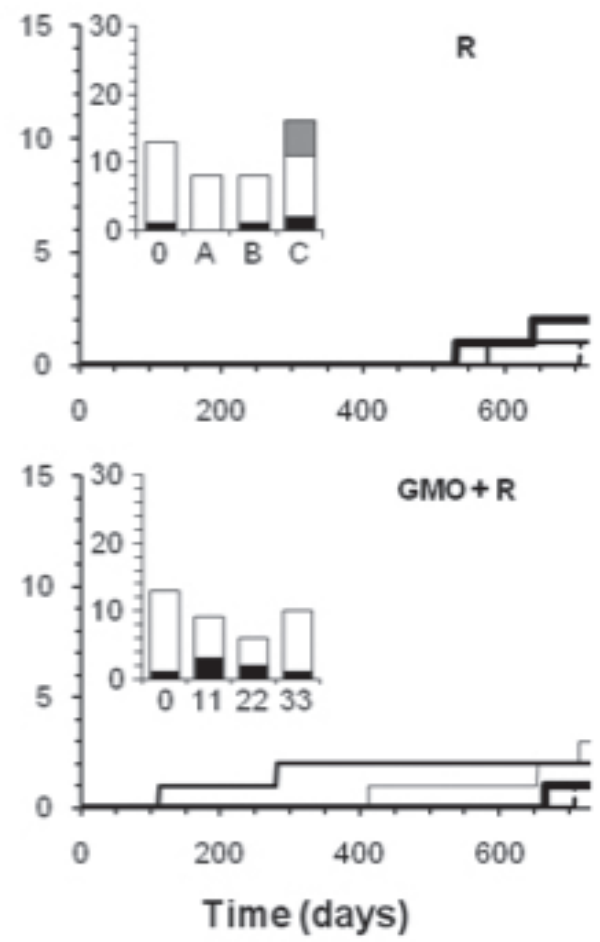

Figure 2. Largest non-regressive tumours in rats fed GMO treated or not by Roundup (R), and effects of Roundup alone [107]. The key to the main graphs is the same as in Fig. 1; control lifespans are not shown. The largest tumours were palpable during the experiment and numbered from $20 \mathrm{~mm}$ in diameter for males and $17.5 \mathrm{~mm}$ for females. Above this size, $95 \%$ of growths were nonregressive tumours. Inset: (bar histograms): summary of all tumours: black, non-regressive largest tumours; white, small internal tumours; grey, metastases.

\section{HOSTILE CRITICISM OF THE SERALINI ET AL. PAPER}

\subsection{Science Media Centre (SMC)}

On the day following online publication, the SMC posted a brief statement and letters from experts [20], entitled "Study on cancer and GM maize - experts respond", which received wide media coverage globally. The most frequently stated criticisms were: not enough rats per group, wrong type of rat and wrong statistical analysis. Two entirely spurious remarks were made by Prof. Maurice Moloney, Institute Director and Chief Executive, Rothamsted Research, who said: "Figure 1 does not provide any data from the controls and their variance is unreported here. Table 2 reports different numbers of individuals used for the controls than the treatments. In all cases the controls have used less individuals than used in the treatments." The complaint about the lack of data on controls in Fig. 1 is surprising, as the controls are clearly shown in the Figure, which has not been changed from the original publication except for a re-arrangement of the panels. The complaint about Table 2 evidently results from a failure to read the description of the table: the numbers of animals refer not to the number used for the measurement but rather to the number having a given pathology, which was smaller for the controls than for the treated groups.

SMC claims to be "an independent press office helping to ensure that the public have access to the best 
scientific evidence and expertise through the news media when science hits the headlines" [21]. However, its funders include large biotechnology companies, and 7 out of the 8 supposedly independent experts who initially wrote letters are heavily associated with the GM industry [22]. They are Dr Wendy Harwood, Prof. Maurice Moloney, Prof. Alan Boobis, Prof. Ottoline Leyser, Prof. Tom Sanders, Prof. Mark Tester and Prof. Anthony Trewavas.

\subsection{Letters to the Editor of FCT}

On the day following publication of the Séralini et al. paper, Letters to the Editor from critics were posted online. A number of letters, both pro- and con-, were published in the March 2013 issue of the journal [23], but not all of those originally sent now appear on the website. The complaints in these letters are similar to those of $\$ 4.1$ and were instrumental in leading to the retraction of the paper 14 months later. Only one is discussed here, by Tester [23], which charges that the study is bad science and should be retracted (a view echoed in some of the other Letters). Tester points to two studies in support of his accusations:

"I am writing to ask that the paper by Séralini et al. be retracted for several reasons [including]:

"A 2008 two-year rat feeding study by Sakamoto et al. found that biotech soybeans pose no health risks.

"A 2012 assessment by Snell et al. reviewed 12 longterm feeding studies of biotech maize, potato, soybean, rice, and triticale and found that biotech crops are nutritionally equivalent to their conventional counterparts and can be safely used in food and feed."

Sakamoto et al. compared the health of rats fed a diet containing $30 \%$ of GM soybeans with that of rats fed a diet containing closely related non-GM soybeans [24]. The study extended over 104 weeks, but the rats were fed GMOs only on 41 days [25]. Some differences were found between treated and control groups, but there was "no meaningful difference" in other parameters. Thus, as in the Monsanto study $(\$ 2)$, differences between treated animals and controls were dismissed as not being meaningful. There were also irrelevant controls to add noise to the data. In any case, safety of one GM crop, soybean, does not ensure safety of another, maize.

Snell et al. compiled 24 studies [26], often cited by GMO advocates as evidence of the safety of GM crops. Fagan, Antoniou and Robinson [8] and Jacquemart [27] showed that safety is an unwarranted conclusion from that work. Some of the 24 studies do not investigate health effects but merely look at aspects like feed conversion and milk production; they are nutritional, not toxicological, studies. Several are not long enough in comparison with the lifespan of the animals or used too few animals. An unacceptable practice in one of the studies was the replacement of half the cows because they were infertile or fell ill; the reasons were not investigated. There were studies on animals that are irrelevant for human health because they have different digestive systems or metabolism. Studies that found harmful effects, such as on liver, kidneys, blood, pancreas and testicles in mice or rats were dismissed.

\subsection{Response of Monsanto}

Monsanto cited the pronouncement (to be discussed in $\S 5.1$ ) of the European Food Safety Authority (EFSA) on the Séralini et al. study, then made a statement in similar vein [28]. It was objected that: "Extensive animal and invitro (test-tube) data has demonstrated that glyphosate does not cause cancer or tumors, nor is an endocrine disrupter." What is notable about this objection is that Monsanto's own studies in the 1980s found tumour development in animals given glyphosate [29]. ${ }^{6}$

\subsection{Further criticisms}

The French Académie des Sciences and five other French Académies issued a joint assessment [30] of the Séralini et al. paper, making the usual complaints and also raising other objections. Later, the unprofessional manner in which the assessment had been made was exposed (see $\$ 7.2(6)$ ).

Lengthy and scathing denunciations of every aspect of the Séralini et al. paper were published by Arjo et al. [31] and the Vlaams Interuniversitair Instituut voor Biotechnologie (VIB) [32]. The main criticisms were discussed and refuted by Loening $(\$ 10.2)$. Bias may be inferred from the statement that "VIB is a world authority in plant research that uses genetically modified plants as a research resource."

The Agence Nationale de Sécurité Sanitaire de l'Alimentation, de l'Environnement et du Travail (ANSES) concluded [33]: "The collective expert assessment carried out by the Agency concluded that the results of this research do not cast doubt on previous regulatory assessments of NK603 maize and Roundup" but did recognize the need for a further long-term study, as will be described in $\S 6(3)$.

\footnotetext{
${ }^{6}$ These confidential studies were obtained via the provision of the Freedom of Information Act from the US Environmental Protection Agency (EPA).
} 


\subsection{Legal cases}

Some attacks have been severe enough to cause litigation, such as assertions of "fraud" and "falsified data". Two lawsuits are described here.

In November 2015 Marc Fellous, former chairman of the French Biomolecular Engineering Commission, was indicted for "forgery" or "use of forgery" of the signature of a scientist without his consent in order to condemn the Séralini et al. paper (Séralini won the case) [34].

In September 2012 Jean-Claude Jaillette, a journalist for Marianne magazine, wrote that the paper of Séralini et al. was a "scientific fraud in which the methodology served to reinforce predetermined results". The following lawsuit, and an appeal against the initial judgment against the magazine and the journalist, finally resulted in a ruling in September 2016 in favour of Séralini's team and the Comité de Recherche et d'Information Indépendantes sur le génie Génétique (CRIIGEN), an organization supporting their research, on the grounds of defamation [34, 35].

CRIIGEN made an announcement [36]: "In 2013 we will take other appropriate legal action in order to make completely transparent the hidden and lax toxicological data, which has allowed [industry], through health agencies, to obtain marketing authorization for the products we tested, amongst others. To lead by example, we place our raw data in the hands of a legal investigator."

\section{THE EUROPEAN FOOD SAFETY AUTHORITY (EFSA)}

\subsection{EFSA's verdict}

EFSA has been assigned a critical rôle in ensuring food safety in the European Union (EU), being responsible for assessing the safety of new, novel products, including genetically modified crops, before they can be introduced commercially. Its judgment of the Séralini et al. paper is therefore of the utmost importance. Unfortunately, in the light of EFSA's history as described below, its negative verdict on the paper of Séralini et al. was predictable.

An initial review was published online by EFSA on 4 October 2012, just 15 days after online publication of the Séralini et al. paper [37]; and the final review was published on 28 November [38], concurring with its preceding judgment. The abstract of the final review states: "The study as reported by Séralini et al. was found to be inadequately designed, analysed and reported ... Taking into consideration Member States' assessments and the authors' answer to critics, EFSA reaches similar conclusions as in its first Statement (EFSA 2012) ...
Conclusions cannot be drawn on the difference in tumour incidence between treatment groups on the basis of the design, the analysis and the results as reported ... EFSA concludes that the currently available evidence does not impact on the ongoing re-evaluation of glyphosate and does not call for the reopening of the safety evaluations of maize NK603 and its related stacks."

\subsection{Background of EFSA}

EFSA's close links with the pro-GM lobbying organization ILSI (discussed in §5.3) cast doubt on the reliability of its appraisals. Papers finding harm from GM crops are harshly criticized by EFSA, unlike papers finding safety, even though they may be scientifically less rigorous [39]. Robinson et al. [40] discuss EFSA's biased evaluation of the Séralini et al. study in comparison with EFSA's acceptance of weaker industry studies, and the infiltration of EFSA and the strong influence on its assessments of GM crops and foods by experts linked to the GM industry and ILSI. Almost from its inception, the agency has been strongly under the influence of the GM industry. The EU Ombudsman and the European Parliament have both criticized the agency for its tolerance of "revolving doors" between EFSA members and the GM industry, which EFSA is charged to regulate [41].

\subsection{The International Life Sciences Institute (ILSI)}

To understand how EFSA operates, it is necessary to introduce ILSI, with which it has been closely linked. ILSI declares [42] that it is a "nonprofit, worldwide organization whose mission is to provide science that improves human health and wellbeing and safeguards the environment." Members of the ILSI Board of Trustees are unpaid volunteers acting as individuals, not on behalf of their employers. ${ }^{7}$ ILSI lobbies on behalf of the biotechnology industry and has played a key rôle in formulating regulations for risk assessment of GM foods and chemicals (see §5.4). The website also states that "ILSI's funding comes primarily from its corporate membership and supporting companies", which include the major GM seed developers. Unsurprisingly, ILSI's activities show bias in favour of industry, and the organization was barred by the World Health Organization (WHO) from taking further part in "setting microbiological or chemical standards for food and water" [44].

\subsection{EFSA's links with ILSI}

Although EFSA claims [45] that its "scientific advice helps to protect consumers, animals and the environment

\footnotetext{
${ }^{7}$ The matter is considered further in a report [43].
} 
from food-related risks", the evidence below reveals its minimal oversight of the powerful GM industry. Safety evaluation is supposed to be based on the precautionary principle but, in fact, EFSA's risk assessments are mostly based on confidential, unpublished studies finding no harm that have been performed, or sponsored, by the companies seeking approval of their product. Published studies by independent scientists that find harm are largely ignored or dismissed [46, 47]. The company experiments have sometimes been documented as being designed to use old-fashioned methods that will not find an adverse effect, or as being grossly manipulated during the testing until conditions for no adverse effect are reached, or as omitting necessary tests altogether $[48,49]$. To account for the lack of proper scrutiny of GMOs, it is only necessary to consider the close links of the EFSA assessors with the GM industry [40].

Harry Kuiper joined EFSA in 2003, the year following the creation of the agency, but continued to be a member of ILSI. In 1998, he was the coördinator of an ILSI project on verification procedures for GMOs [41]. From 2003 to 2012 (the end of his term), he was Chairman of the GMO Panel of Experts. Before 2003, he had been working with ILSI and the biotechnology industry on examination requirements for risk assessment of GMOs [50]. His published papers on risk assessment from his time at ILSI promote the concept of "comparative assessment" [41]; i.e., comparison of certain characteristics of a GM plant with those of a non-GM plant to determine whether they are similar. If they are sufficiently similar, no comprehensive assessment need be done. He was also a member of working groups at WHO and the Food and Agricultural Organization (FAO), both of which are part of the United Nations. Kuiper's influence thus spread to many quarters, giving the appearance that many seemingly independent organizations were in agreement on GMOs [41]. According to Testbiotech and Corporate Europe Observatory, Kuiper "has been involved in each and every one of the risk assessments of genetically engineered plants since the start of EFSA" [41]. At least until November 2012, there had not been a single application of the stringent "comprehensive assessment" [41]. Kuiper's case was referred to the EU Ombudsman in March 2012, who asked EFSA to respond. EFSA repudiated the charges of conflicts of interest as complying with EFSA's rules at the time, and stated that new rules had since been put in place [51]. Those rules, however, albeit improvements, are still inadequate.

Juliana Kleiner [52], Suzy Renckens [41, 47, 53-55] and Diána Bánáti [41] similarly held high-ranking positions at EFSA and were also involved with either ILSI or the biotechnology company Syngenta.

\subsection{Criticisms of EFSA}

EFSA came under heavy criticism for the way it handled its review of the Séralini et al. paper. A major criticism was the choice of Andrew Chesson as a reviewer, as he had participated in the original approval of NK603 for use in the EU and was also one of two EFSA panel members who oversaw its final review of the Séralini et al. paper. Thus he was asked to pass judgment on a paper that would overthrow his previous acceptance of the safety of maize NK603 for consumption. This constituted a clear conflict of interest [56]; bias in his judgment would have potential consequences for the health of millions of consumers. His co-reviewer also had a conflict of interest [57].

The EU Parliament refused to release EFSA's budget for 2010, criticizing the conflicts of interest and the links with ILSI [41]. Release of the budget again failed in May 2012 but was agreed later in the year [58]. The EU Commission, also heavily pro-GM, came under attack by Member States when, in June 2012, the Commission proposed to appoint Mella Frewen, a former Monsanto employee and lobbyist for the food industry, to membership of EFSA's administrative board [41]. She had lobbied for GM plants to be allowed in food even if they had not been approved in the EU. Gijs Kleter was also nominated in 2012 and was appointed ViceChairman of the GMO Panel, although he had worked at ILSI between 2002 and 2007 on risk assessment of GM plants [40, 59]. The EU Parliament in 2014 voted on a resolution to ban scientists linked to the agriculture or food industries from employment by EFSA, but EFSA defended itself against the charges [60, 61].

EFSA has insufficient funds to employ experts on the GMO Panel, who are all volunteers [62]. Without financial remuneration, there must be some other motivation for a Panel member to offer his or her time and services. The cases cited above suggest that the motivation, and reward, come ultimately from the GM industry.

When the US Science Advisory Panel met in December 2015 to review EFSA's assessment of glyphosate prior to the decision whether it should be reapproved, a number of problems were found, including tampering with data and failure to comply with the guidelines. A Panel member concluded that: "The available evidence did not fit with the conclusions drawn in the issue paper, particularly when put in the context of the guidelines" [63].

Most recently, in July 2017, EFSA has been castigated [64] by a toxicologist for its finding that glyphosate is not carcinogenic, a conclusion opposite to that of the WHO expert panel on cancer, the 
International Agency for Research on Cancer (IARC). EFSA's assessment had failed to include several studies finding cancer in laboratory animals while including clearly deficient studies finding no cancer. The assessment procedure, furthermore, violated some legal EU requirements and OECD guidelines.

\section{FURTHER LONG-TERM EU STUDIES}

(1) Member States of the EU were alarmed by the results of the Séralini et al. study and pressed for a new European, long-term (2-year) study to confirm or refute those results.

In December 2012, EFSA agreed to assist with the design of such a study. However, shortly after Juliana Kleiner assumed the post of Director of Science Strategy and Coördination at EFSA, its Scientific Committee expressed concerns about the usefulness of such a study, and made recommendations that would have severely weakened it. These discussions were led by Per Bergman, who had led a task force to discredit the Séralini et al. paper just after it was published. Eventually, in August 2013, EFSA provided new guidelines for future 2-year feeding trials to test for chronic toxicity and/or carcinogenicity [65]. They vindicated some contested points of the experimental design features of the Séralini et al. study, including the strain of rats used. They also warned that reference and historical controls must be used "with caution", ensuring similarity of diets.

The recommendations included the following: "Rodents are the preferred animals to be used in long term studies, due to their relatively short life span ... [and] their susceptibility to tumour induction... The study should be carried out in animals from the same strain and source as those used in the preceding toxicity study(ies) of shorter duration, unless scientifically justified (OECD, 2009a)." These guidelines, intended for combined toxicity and carcinogenicity studies, allow a minimum of 10 animals per sex per group, although for a "stand alone" toxicity study, at least 20 animals per sex per group should be used [ $65, \mathrm{p}$. $7 ; 66]$. Because these guidelines became available only in the year following the publication of the Séralini team's paper, those researchers relied on an existing guideline, OECD 452 for chronic toxicity studies of chemicals [66]. Séralini et al. commented: "This remains the highest number of rats regularly measured in a standard GMO diet study."

(2) The GRACE (GMO Risk Assessment and Communication of Evidence) project was funded by the EU Commission [67]. One of its undertakings was evaluation of Monsanto's GM maize MON810, the only GMO approved for cultivation in the EU. Unfortunately, the "long term" that had been planned was reduced, and the duration was limited to the usual 90 days favoured by industry [68]. About half of the expert participants in the Project had unacknowledged links to the biotechnology industry [69]. The results were published in a journal that had two leading editors and a third editor connected with the GM industry. Independent reanalysis of the data [68] came to the conclusion that the treated animals suffered damage to the liver, kidneys and pancreas, although the GRACE authors concluded that the maize caused no harm. This disagreement is of great concern, because the EU Commission plans to use the outcomes of these feeding trials as the basis for future standards of risk assessment of GM plants in the EU.

(3) Plans for a French long-term study

The French ANSES planned long-term feeding studies, having reviewed the literature and found only two other studies besides that of Séralini et al. lasting the lifetime of the subject animals [30]. The trial was launched in July 2013, but once again its terms were weak. Monsanto (whose GM maize MON810 was to be studied) and other companies were to participate; and the "long-term" duration was reduced to 6 months, or possibly only 3 months. As suggested by Figs 1 and 2, even the longer duration is unlikely to reveal clear results. Séralini, who had initially been a participant, felt obliged to withdraw on the basis that "the proposed study is insufficient and will thus be inconclusive" [70].

(4) The international "Factor GMO" study

This longest and most ambitious study of a GM crop and its associated pesticide ever undertaken, called Factor GMO, [71] was launched in November 2014. It was to last for 5 years and to cost $\$ 25$ million raised from sources, including the public, unconnected with the GM or pesticide industries. The scientists carrying out the work had to be be neutral and independent, and therefore related neither to the GM or pesticide industries nor to the anti-GM movement. Unfortunately, the project appears to be stalled.

\section{DEFENCE OF THE SÉRALINI ET AL. STUDY}

\subsection{Authors' answers to critics}

In March 2013, Séralini et al. [72] published (in FCT) a response to the criticisms of their 2012 paper. They point out that theirs is "the most detailed study involving the life-long consumption" of an agricultural genetically modified organism (GMO)" and also "the first long term detailed research on mammals exposed to a highly diluted pesticide in its total formulation with adjuvants ... This is a first step in the iterative investigation of the long-term health effects on mammals of these commercial products that should be replicated independently, as well as on developing mammals." 
A table of 21 points of contention was addressed, including: protocol not adapted to tumour findings; lack of signs in 90 days; choice of the rat strain; number of rats per group; controls not sufficient; no reference groups, no lab historical data; not enough statistical power; endocrine disruption not sufficiently supported; Roundup is not a sex endocrine disruptor; glyphosate is not toxic in two-year tests; Sakamoto et al. 2008 not cited; raw data expected for the [Séralini] study; conflicts of interests and rôle of funders. All points were defended or explained.

"Protocol not adapted to tumour findings" is refuted by the reminder that this was a toxicity study, not a carcinogenicity study. "Lack of signs in 90 days" is irrelevant in the light of many signs over the following two years; and the authors state that "Statistical differences in biochemical parameters of liver and kidney function [are] recognized by both industry and agencies." The use of only one control group is defended as avoiding variable factors, including unwanted GMOs and the pesticides found in many standard laboratory diets (see $§ 14.1$ ).

\subsection{Support from other scientists}

(1) The European Network of Scientists for Social and Environmental Responsibility (ENSSER) issued a statement on 5 October 2012 [73] after comparing the Séralini et al. study with published industry studies. Its conclusion was that most objections to it are either wrong or based on double standards, and that it is to be expected that the regulators (including EFSA), which have demonstrably close links with industry, would not wish to alter their previous, positive assessment of NK603 because that would jeopardize their credibility

(2) Rebelle-Santé commented [36]: “11 January [2013], in its press conference, CRIIGEN, which originated the study, announced that it has received the support of more than 300 scientists from 33 countries and 5 continents."

(3) Many supporting Letters to the Editor were sent to FCT, but only one will be cited here. Jack Heinemann, of the University of Canterbury, New Zealand, wrote a noteworthy answer to critics' objections [74], including the following:

"I performed a quick review of papers on rat feeding studies using genetically modified feed components also published in this same journal. In addition to the paper by Séralini et al., I found seven studies between 2004 and now ...

"These studies used approximately the same number of rats as the study by Séralini et al. All of them used the same kind of rat as the Séralini et al. study ...

"The statistics used in these other studies passed anonymous peer-review. Aside from that, there is no other peer-reviewed evidence that these statistical approaches are either uniquely appropriate or validated for their use in this kind of study ...

"Where the Séralini et al. study has no peer in this group of papers is in its duration. No number of 90-day feeding studies can refute the findings of a long-term study when the effects are largely those that appear after 90 days.

"Some critics have attempted to disparage the most recent findings by drawing doubt on the nature of the response, pointing out that the severity of the effect did not uniformly increase with dosage. I am aware of a number of toxicological studies that report similar phenomena. For example, Welshons et al. (2003) said in their article in Health Perspectives: 'Furthermore, receptor-mediated responses can first increase and then decrease as dose increases, contradicting the assumption that dose-response relationships are monotonic.' The effect fits perfectly well with receptor-mediated or saturated effects and within the hypotheses presented by Séralini et al."

(4) An open letter [75] signed by over 140 scientists around the world supported the Séralini et al. study and also described previous cases of vilification of science and scientists who found harm from GM crops. The letter also denounced the science media and the inadequacy of regulating agencies. "The Séralini publication, and resultant media attention, raise the profile of fundamental challenges faced by science in a world increasingly dominated by corporate influence. These challenges are important for all of science but are rarely discussed in scientific venues."

(5) An article published in Le Monde [76], signed by 140 French, scientists condemned the manner in which the Académie des Sciences' statement (see §7.2 (5)) had been organized, without debate, by a dozen representatives. It then condemns the critics who do not accept the protocol followed by Séralini et al. although they accept the same protocol in studies that support GM, upon which regulatory approval is based.

(6) The assessment by the Académie des Sciences (§4.4) did not represent all of the Académies but had been hastily produced by a committee of two members from each of the six. One of these academicians was Georges Pelletier, who had been involved in the EU regulatory approval of NK603 and had previously attacked Séralini $[77,78]$.

An academician whose views were not represented by the Académies' condemnatory statement was Paul Deheuvels, who had not even been aware of the statement until after it had been issued [79]. As an eminent statistician, the only one at the Académie des Sciences, Deheuvels should have been consulted. He 
examined the raw data and defended the statistical methodology adopted by the Séralini team, and deplored "the pressures that are applied to manipulate the Academy, and to transform it into a lobbying tool."

(7) Regarding the charge that too few animals were used to demonstrate that the treatments caused the formation of tumours, the statistician Deheuvels pointed out that the occurrence of tumours in these small groups actually makes it more likely that the treatments are the cause [80]. The argument is that a large number of rats is needed for a carcinogenicity study because, if cancer is a rare occurrence, cancers might not be present in a small group (a false negative), although some cancers would be expected in a large group. The presence of many cancers in a small group suggests a high incidence among that population.

(8) A former research analyst with a major government agency (who did not wish to be named) also dismissed the objections to the statistical methodology [81].

(9) Loening [82] argued that the most appropriate strain of rats had been used, because other strains less susceptible to tumours might not have revealed these symptoms; and "a few diseased animals suffice to confirm a lack of safety." Others have argued that being prone to cancer makes the rats more like humans, who are also prone to the disease.

\section{RETRACTION OF THE SERALINI ET AL. PAPER}

\subsection{Editor's letter and Publisher's statements}

Prior to the retraction, FCT and its publisher, Elsevier, issued a brief statement [83] that they had received "many questions" about the paper from scientists, that a "thorough peer-review process" had been applied and that the sending of letters with concerns to the Editor-inChief was encouraged. The letters would be considered for publication by the editors.

FCT undertook an exceptional and lengthy second peer review, in which the authors complied with the unusual request to supply all the raw data. Then, on 19 November 2013, more than a year after online publication of the paper, the Editor-in-Chief, A. Wallace Hayes, wrote to Séralini asking him to withdraw the paper as otherwise it would be retracted and a retraction statement that was included in the letter would be published [84].

Séralini refused to withdraw the paper.

On 28 November 2013, the publisher duly issued the retraction statement contained in the letter to Séralini [85]:

This retraction comes after a thorough and timeconsuming analysis of the published article and the data it reports, along with an investigation into the peer-review behind the article ... Very shortly after the publication of this article, the journal received Letters to the Editor expressing concerns about the validity of the findings it described, the proper use of animals, and even allegations of fraud ... Due to the nature of the concerns raised about this paper, the Editor-in-Chief examined all aspects of the peer review process and requested permission from the corresponding author to review the raw data. The request to view raw data is not often made ... The corresponding author agreed and supplied all material that was requested by the Editor-in-Chief. The Editor-inChief wishes to acknowledge the co-operation of the corresponding author in this matter, and commends him for his commitment to the scientific process ... Unequivocally, the Editor-inChief found no evidence of fraud or intentional misrepresentation of the data. However, there is legitimate cause for concern regarding both the number of animals in each study group and the particular strain selected ... A more in-depth look at the raw data revealed that no definitive conclusions can be reached with this small sample size regarding the role of either NK603 or glyphosate in regards to overall mortality or tumor incidence ... Ultimately, the results presented (while not incorrect) are inconclusive, and therefore do not reach the threshold of publication for Food and Chemical Toxicology ... The Editor-in-Chief again commends the corresponding author for his willingness and openness in participating in this dialog. The retraction is only on the inconclusiveness of this one paper.

Thus, the paper was to be withdrawn because of the small number of animals in each study group and the particular strain selected: the Editor-in-Chief was accepting the erroneous view that this was a carcinogenicity study, a view corrected repeatedly by the authors and by many other scientists but steadfastly ignored by critics.

\subsection{Grounds for retraction}

\subsubsection{Elsevier's policy on retraction}

The Publisher has a policy [86] regarding retraction of papers, which includes the following:

Infringements of professional ethical codes, such as multiple submission, bogus claims of authorship, plagiarism, fraudulent use of data or the like. Occasionally a retraction will be used to correct errors in submission or publication. The retraction of an article by its authors or the editor under the 
advice of members of the scholarly community has long been an occasional feature of the learned world.

8.2.2 Committee on Publication Ethics (COPE) grounds for retraction

COPE has published guidelines for retraction, here given in summary [87]:

Journal editors should consider retracting a publication if:

- they have clear evidence that the findings are unreliable, either as a result of misconduct (e.g. data fabrication) or honest error (e.g. miscalculation or experimental error)

- the findings have previously been published elsewhere without proper cross referencing, permission or justification (i.e. cases of redundant publication)

- it constitutes plagiarism

- it reports unethical research

None of the above was applicable to the paper of Séralini et al.

\subsubsection{Further statement by the Editor-in-Chief}

On 10 December 2013, A. Wallace Hayes published a more detailed explanation for his retraction of the paper on the Elsevier website [88]. The reasons for retraction are repeated, but the statement also refers to many Letters to the Editor from scientists supporting the Séralini et al. paper that express concern about the involvement of Richard Goodman, an editor with a strong pro-GM bias (discussed in §9) as well as possible influence by Monsanto and whether the guidelines on retraction formulated by COPE had been followed. It was acknowledged that Richard Goodman was "involved in initial discussions of the Séralini paper and the request to view raw data ... Further, when Dr Séralini asked for Dr Goodman's involvement to stop, I agreed, fully and promptly ... The data are inconclusive, therefore the claim (i.e., conclusion) that Roundup Ready maize NK603 and/or the Roundup herbicide have a link to cancer is unreliable ... However, to be very clear, it is the entire paper, with the claim that there is a definitive link between GMO and cancer, that is being retracted ..."

The principal issue leading to retraction is thus the "claim" that the GM maize and/or Roundup are linked to cancer; in fact, the word "cancer" never appears in the paper. Moreover, the toxicological conclusions had not been contested, yet the entire paper was retracted. As this was a toxicology study, one could argue that at least the toxicological findings should have been retained.
There is no justification for the retraction on the grounds allowed by COPE. Unreliability on the grounds of inconclusiveness appears to be an invention of the Editor-in-Chief. If applied more generally, many papers already published would have to disappear. Among the papers that are not disappearing is the 2004 Monsanto study [7] discussed in \$2: the Editor-in-Chief continues the statement quoted above with the remark that some letters questioned whether the Monsanto study had received different treatment from the journal, and he responded by re-examining that paper-but did not retract it.

\subsection{Editors' conflicts of interest}

Testbiotech [89] discovered that the Editorial Board of FCT had numerous cases of conflicts of interest. The conflicts of interest at EFSA and ILSI, to which some members belong, have already been described in $\$ 5.4$. Testbiotech discovered that although the names of the experts responsible for the review of the Séralini et al. paper have not been made public, several members of the editorial board of FCT have ties with industry, with ILSI or with EFSA, which is defending its own opinions claiming that products such as NK603 are safe. Note:

- Richard Goodman, former Monsanto employee, who worked with ILSI;

- Brian Delaney, employee at Pioneer/Dupont;

- Susan Barlow, former expert at EFSA, worked with ILSI;

- Ivonne Rietjens, former expert at EFSA, worked with ILSI;

- David J. Brusick, consultant for pharmaceutical and chemical companies, former leading staff member of Covance Laboratories, which are a service contractor for Monsanto (feeding studies with genetically engineered plants);

- William C. Hall, Hall Consulting, formerly with Charles River Laboratories, which are a service contractor for Monsanto (studies on glyphosate);

- Palma Ann Marone, Product Safety Laboratories, which are a service contractor for agrochemical industry (studies on glyphosate);

- Claire L. Kruger, consultant for pharmaceutical and chemical companies;

- Dieter Schrenk, EFSA.

A. Wallace Hayes was at the time in question also senior science advisor at Spherix Consulting, which "provides scientific and strategic support for suppliers, manufacturers, distributors and retailers of conventional foods, biotechnology-derived foods ... consumer products, and industrial chemicals and pesticides" [90]. The company also assists clients with "fulfilling data needs and submitting application packages to the EPA for 
all categories of pesticide: antimicrobials, biopesticides and conventional, including bactericides, baits, fungicides, genetically modified organisms (GMOs) or biological pesticides, herbicides, insecticides, lures, rodenticides and repellents" [91]. Further conflict of interest was unveiled by the Monsanto Papers, discussed in $\S 15$.

\section{THE ROLE OF RICHARD GOODMAN}

\subsection{Appointment as Associate Editor for Biotechnology}

\subsubsection{Warning letter to FCT and Elsevier}

A few months after the publication of the Séralini et al. paper, FCT created a new post of Associate Editor for Biotechnology and, to fill it, quickly appointed Richard Goodman, a research professor at the University of Nebraska in the Food Allergy Research and Resource Program [92]. His association with ILSI and former employment at Monsanto were already well known. In view of the aggressive pressure Monsanto had applied previously to stop broadcast or publication of material that would put the company in a bad light, and even threats of lawsuits against individual states of the United States if GM labeling laws were passed, in October 2013 eight scientists signed and sent an open letter [93] to several staff members at Elsevier and to A. Wallace Hayes to warn of the dangers of employing Richard Goodman as an editor. One outcome of this letter was the offer from the Publisher to the signatories that they might recommend a scientist who would be considered for a new post of editor to counterbalance Richard Goodman's influence. A nomination was made, but the process halted abruptly on both sides when the Séralini et al. paper was retracted.

\subsubsection{How Goodman described his appointment}

Answering an online question, Goodman replied at length [92]:

"I was employed at Monsanto in Regulatory Sciences from 1997 until July 2004, and worked on the safety assessment of genetically engineered crops during that time and as researcher, and continue with similar work since then. My work includes evaluating GMOs and novel food ingredients developed by non-profit and for-profit entities.

"I manage the Allergenonline.org database, which is funded by the six major biotechnology companies [Monsanto is one of those companies].

"When the Séralini paper was published I was one of the primary critics of the editors of Elsevier for allowing this clearly deficient and sensationalistic paper to be published without apparent adequate peer review. I saw a number of deficiencies in the paper and wrote a critical letter to the editor (as did many scientists both within and outside of the biotech industry) ... The editor contacted me to inquire whether I was willing to become an Associate Editor to handle the review process for manuscripts related to biotechnology. I reluctantly agreed. I do receive a very small honorarium for the effort (probably less than $\$ 5$ per hour spent on the assignments). The work is done outside of my normal university responsibilities."

One might question the wisdom of having a Monsanto-connected reviewer for a paper finding harm associated with two of Monsanto's products.

\subsection{E-mail correspondence with Monsanto}

The consumer advocacy organization "US Right To Know" obtained e-mails via the Freedom of Information Act, from which Stéphane Foucart wrote an article for $L e$ Monde [94]. The translated extracts below include comments by Claire Robinson [95]:

"Goodman himself wrote in a message of 2012 that $50 \%$ of [his] salary actually comes from a project funded by Monsanto, Bayer, BASF, Dow, DuPont and Syngenta [the 'Big Six' companies for GM], and consisting of establishing a database of food allergens.

"On 19 September, Foucart writes, Goodman informed his Monsanto correspondent about the publication of the Séralini article and that he 'would appreciate' it if the firm could provide him with criticisms. 'We're reviewing the paper,' the Monsanto correspondent replies 'I will send you the arguments that we have developed.' A few days later, Foucart writes, Goodman was named 'associate editor' of FCT, on the decision of the toxicologist Wallace Hayes, then editor of the journal.

"This appointment was not publicly announced until February 2013 ... On 2 November 2012, when the 'Séralini affair' was in full flow, Hayes announced in an e-mail to Monsanto employees that Goodman would from now on be in charge of biotechnology at the journal. Hayes added: 'My request, as editor, and from Professor Goodman, is that those of you who are highly critical of the recent paper by Séralini and his co-authors volunteer as potential reviewers."

Asking Monsanto employees to become referees for a paper finding serious harm to health from Monsanto products was another instance of unwise behaviour on the part of the Editor-in-Chief.

\section{REACTIONS TO THE RETRACTION}

\subsection{Responses by Séralini and his team}

On the day of the retraction Séralini and his team issued a statement condemning the action as being unjustified [96] The authors state that answers to some of the criticisms 
had already been published in FCT, and they had not been contested. The number and type of rat used was defended, and the use of historical controls in the Monsanto study [7] was shown to falsify health risk assessments. Thus, double standards were being used by FCT to evaluate papers finding harm from GM as compared with papers finding safety. A call was made to retract the Monsanto study.

In a press release issued on 4 March 2014 [97], the Serralini team stated that they believe "the withdrawal does not meet the ethical requirements set by COPE", and that "Hundreds of researchers are supporting Séralini's team in what has become a struggle for the defence of scientific ethics and the independence of research. At the end of February, it was the turn of a former member of the editorial board of the CTF [FCT], Marcel Roberfroid, to express his indignation at $\mathrm{Dr}$ Hayes over the retraction: 'Your decision can be interpreted as the desire to eliminate scientific information that does not help to support industrial interests, which seems unacceptable to me'." Prof. Séralini added that this was a matter of public health and asked the Editor and the Académies for a debate.

In July 2014, the Séralini team published a reply [98] to the Editor-in-Chief's second statement about the retraction [88]. They compared their study with another recently published in FCT, that of Zhang et al. [99] (see $\S 12.4$ ), which should have been rejected if the same criterion of inconclusiveness had been applied. Once again, they point out that the strain of rat and number per sex per group were correct for their toxicity study. The main part of the paper deals with biological parameters relating to the function of various organ systems, and those results should have remained in the scientific record. It is the only paper to provide blood analyses of animals given Roundup rather than glyphosate alone. The Monsanto study [7] remains in print, even though it concluded that NK603 is "safe and nutritious", contrary to findings of potential toxicity to liver and kidneys when the raw data were re-analysed [100], after having been obtained by court order. Those early indications of harm to health were vindicated in the Séralini et al. long-term study. The authors conclude that double standards are being applied and that papers finding safety are not subjected to the same scrutiny, Thus "economic interests have been given precedence over public health."

\subsection{Paper by Loening}

Loening published a detailed "critique of the critics" of the Séralini et al. study after the paper was retracted [101]. Frequently cited were the paper of Arjo et al. [31] and the report by VIB [32]. In discussing early deaths and the incidence of tumours, Loening pointed out that critics have concentrated on the numbers of affected rats at the end of the study, but a meaningful interpretation must take account of the times of death and the appearance of tumours. When that is done, the results shown in Figs 1 and 2 suggest that the effect is real. In the case of tumours, aging would have affected the results at the end of the study. Loening dismissed criticisms of the use of Roundup rather than glyphosate, as it is Roundup that is used in agricultural practice. Dose effects should not necessarily be expected to be monotonic. The 90 -day protocol has no basis, but was adopted after being arbitrarily set by Monsanto. In summary, the flaws or omissions in the criticisms may be due to misreporting of other evidence, misunderstanding, unwarranted assumptions or misreading of data.

Loening then considered what underlay the criticisms, and concluded that "Those who have worked on or tried to publish findings that run contrary to a prevailing consensus have been condemned or ignored and suffered years of opposition, even if proved to be ultimately correct ... such attitudes of vilification undermine and ultimately prevent scientific progress." In the final section of the paper, Loening asked: "How is it that many distinguished gene transfer scientists have condemned Séralini et al. so vehemently on such a weak basis? ... I have to conclude that long and deep engagement in the science of gene transfer ... and safety testing has resulted in a blindly accepted consensus among a circle of gene engineering interests that makes any contradictory findings unacceptable. One is justified in asking [as in Heinemann [75]] whether the criticism was motivated by something other than science, some conscious or unconscious imperative to defend the current [conventional wisdom of the dominant group] (which is supported, one may note, by large corporate interests ...)".

\subsection{Other responses}

(1) ENSSER stated on 29 November 2013 that the retraction is a "travesty of science and looks like a bow to industry" [102].

(2) Meyer and Hilbeck published a comparative study [103] of the Séralini et al. paper and two papers by Monsanto on the same GM maize, NK603, to determine how the studies compared under retrospective application of EFSA's recent evaluation criteria for feeding trials. Their conclusion was that the degree of compliance of both the Séralini et al. study and the Monsanto studies were similar. However, only the Séralini et al. paper had been rejected by EFSA. Hardly any of the criteria applied to the Séralini et al. study had been imposed by 
EFSA on 21 other rat-feeding studies lasting at least 12 months. The conclusion was that double standards prevailed between evaluation of the Séralini et al. study and the evaluation of other studies.

(3) The Institute of Science in Society (ISIS) wrote a report [104] describing the issues already mentioned here and ending with a call to boycott the publisher, which was signed by 1402 scientists and 4034 non-scientists from 100 countries [105].

(4) A supporting statement from End Science Censorship was signed by 182 scientists and other experts from around the world [106].

\section{REPUBLICATION}

Séralini et al. republished their paper, with alterations to the text but not to the science, in June 2014 in Environmental Sciences Europe [107]. That journal was chosen, out of five that offered to republish it, because it offered open access. Files of raw data were also made available.

In the same issue of the journal, Séralini and three other members of his team published a paper about conflicts of interest, confidentiality and censorship in health risk assessment [108]. They describe the experiment and the hostile response, including several papers with ad hominem criticism and false assertions about the Séralini et al. paper. The undisclosed conflicts of interest of these critics are mentioned, as are the names of many critics who wrote to FCT in the days following the 2012 publication and who also had undisclosed conflicts of interest. Even Monsanto, the owner of the GM maize investigated by Séralini et al., claimed to have no conflict of interest. Neither were EU regulators free from conflicts of interest. The contrast is made between the handling of their paper and that of Monsanto [7], which used the same strain and number of measured rats for a study lasting only 90 days; if 10 rats per sex per group are insufficient to show toxicity, then they are assuredly too few to demonstrate safety, and the Monsanto paper should be retracted. Also cited is a study [109] revealing that research concluding that GM products are safe tends to come from industry or from researchers with financial or professional interests in the GM industry. The herbicide Roundup has never before been tested in its full formulation: only its active ingredient (glyphosate) has been assessed, although the adjuvants can make it thousands of times more toxic. Data relating to public health should not be kept confidential. Assessment of new products should not be based on company studies but rather on research by independent laboratories that are funded by the companies but without intervention by the companies in the scientific process. Ultimately, the necessary reforms would reduce public health costs and promote public trust in companies and in science.

Monsanto does not publish its raw data, although EFSA (to the anger of Monsanto) did release their toxicological data on NK603, albeit in pdf format that makes it unusable for statistical analysis. Monsanto's agreement is requested before it is used.

\section{OTHER PAPERS ON GMOS IN FCT IN 2013 AND 2014}

\subsection{Withdrawal of a paper}

Before the arrival of Goodman at FCT, a Brazilian paper was in press and already published on the FCT website [110]. The reported study fed Swiss albino mice with the Cry toxins that are expressed in a large class of GM crops (Bt crops intended to deter pests). That paper found harm to the health of the mice. Shortly after Goodman's arrival, the paper was withdrawn (but quickly reappeared in another journal [111]).

\subsection{Rejection of a paper}

In 2013, a study of chronic toxicity of the leaves of another Monsanto GM maize, MON810, reported harmful effects on body size and fecundity of Daphnia magna, a type of water flea that is used as a model organism by ecotoxicologists. It was Goodman who informed the authors that the paper had been rejected; however, it was published in another journal in 2015 [112].

\subsection{Publication of an industry paper}

In April 2014, DuPont scientists Delaney et al. published the results of a 13-week rat-feeding study of processed meal and oil from seeds of a GM canola (DP-073496-4) that had been developed by DuPont [113]. The same strain of rats, Sprague Dawley, was used as in the work of Séralini et al.. The number of rats was only slightly greater: 12 animals per sex per group compared with 10 by Séralini et al. The authors concluded that the processed meal and oil were "as safe and nutritious" as those from non-GM canola.

Mesnage et al. disagreed with the conclusion [114]. Analysis by accredited laboratories of the type of feed given to the control rats disclosed that it contained 33\% of GM maize ( $18 \%$ of NK603 and 15\% of MON810), as well as $100 \mathrm{ppb}$ of glyphosate and $200 \mathrm{ppb}$ of AMPA, the main metabolite of glyphosate. This contamination invalidates the conclusion of safety for consumption and might justify retraction of the study. The decision to retain the paper is important, as the study can serve to support applications for regulatory approval of the canola. This 
has indeed happened in at least one case, in a risk assessment by the Australian government [115].

In reply to the charge by Mesnage et al., Delaney replied that "the diets that were produced for our study were prepared specifically for DuPont Pioneer and stored at the testing facility where the study was conducted. Mesnage and co-workers did not conduct analysis of the control diets in our study" [116]. This reply does not deny that the contaminants were present. A proper refutation should have included an analysis of the control feed that was used, to prove that no GMOs, glyphosate or AMPA were present. §14.1 describes a study by Mesnage et al. [117] revealing heavy contamination of many standard commercial rodent diets, including the type used by Delaney et al. (Purina 5002), except that they substituted canola for soybeans.

The response by the CRIIGEN team to Delaney et al. [116] included some of the comments made above and also the observation that the lead author of the paper, Bryan Delaney, and Richard Goodman were both on the Editorial Board [118].

A letter sent to A. Wallace Hayes and three others at FCT or Elsevier, pointing out the conflicts of interest in the Delaney et al. paper [119], drew a reply from Hayes. He gave assurance that, although Delaney is a Managing Editor, he did not participate in the review process, which he (Hayes) handled himself. On the matter of all the authors declaring "None" in the box of the Transparency Document in which authors are asked to "state any competing interests", Hayes's reply was "Excellent observation and an oversight on our part. We should have required the authors to affirm that they are employed by DuPont and that the study was funded by DuPont."

\subsection{The Zhang et al. paper}

In 2014, a study was published in FCT by Zhang et al. on the effects of the transgenic insect-resistant rice carrying CrylAc and sck genes [99], which was fed to Sprague Dawley rats (the same strain used by Séralini et al.) for either 52 or 78 weeks. The total of 180 rats was divided into groups according to gender and weight. Some rats received a diet with the GM rice, while two categories of controls were given: either a diet with non-GM rice or an irrelevant diet, AIN-93. Out of 30 animals in a group, only 10 were selected and measured for serum biochemistry. Zhang et al. found no differences in mortality rates, tumour incidence or pathological findings between the treated and control groups. They concluded that "Although certain differences in some hematology, serum chemistry parameters and relative organ weights were observed between GM rice and control groups, they were not considered as treatment-related." Thus, as in the Monsanto 2004 paper [7], significant differences were dismissed and the study concluded that the rice is as "safe and nutritious as the parental rice". Séralini and some of his team members responded with a paper in FCT [98] (already described in §10.1).

\subsection{Monsanto's 2004 paper remains}

Despite the flaws, including the more recent finding that all the feed, including that of the "control" rats, almost certainly contained other GMOs, the 2004 paper by Monsanto scientists remains in print in FCT [7]. That paper was used by EFSA in assessing the safety of Monsanto's GM maize NK603, which subsequently received approval for use as food and feed in the European Union.

\section{CHANGES AT FCT}

Early in 2015 there were changes among the editors at FCT. A new Editor-in-Chief was in place, Jose L. Domingo, who had published papers taking a balanced view of genetically engineered crops. Meanwhile, the former Editor-in-Chief, A. Wallace Hayes, remained as Editor-in-Chief for Vision and Strategy. He is now an emeritus editor. Richard Goodman left the journal at the beginning of 2015. That the climate regarding GMOs has changed is confirmed by the fact that the Séralini team published another paper in FCT as early as 2015.

\section{FURTHER DEVELOPMENTS}

\subsection{Contamination of laboratory feeds}

Diets used in rodent-feeding trials are made up using standard laboratory formulations as a basis, to which a test article, or substitute for the test article in a control diet, is added. In 2015, Mesnage et al. [117] examined 13 such diets from 5 continents. "All diets were contaminated with pesticides (1-6 [different pesticide residues per feed] out of 262 [pesticides] measured), heavy metals ( $2-3$ out of 4 , mostly lead and cadmium), PCDD/Fs (1-13 out of 17) and PCBs (5-15 out of 18). Out of 22 GMOs tested for, Roundup-tolerant GMOs were the most frequently detected, constituting up to $48 \%$ of the diet. The main pesticide detected was Roundup, with residues of glyphosate and AMPA [aminomethyl phosphonic acid] in 9 of the 13 diets, up to 370 ppb." Only two of the diets, both from Italy, did not test positive for any of the GMOs tested. The Purina LabDiet 5002, from the USA, is often used in GM toxicity tests, but is not tested for GMOs or glyphosate, even though these contaminants are almost certainly present: 
maize and soya are common ingredients in rodent diets, and both soya and maize are about $90 \%$ GM in the USA, with soya especially likely to have been treated with Roundup herbicide. The Purina LabDiet 5002 was found by Mesnage et al. [117] to contain 48\% GMOs: $12.8 \%$ GM soy and $35.6 \%$ GM maize, plus a small amount of GM oilseed rape, which were not labeled. Of all the diets measured, this had the second highest level of herbicide residues detected, consisting solely of glyphosate and AMPA at a level of $310 \mathrm{ppb}$.

The Monsanto 2004 paper [7] described the feed used: "Diets containing test, control and reference control grain were formulated by Purina TestDiet (Richmond, Indiana) to be nutritionally and compositionally comparable to Purina Mills, Inc. Certified Rodent LabDiet ${ }^{\mathbb{B}} 5002$. Many toxicology laboratories use this diet in rodent feeding studies." Thus, the diet in the experiment was made in the USA and was "comparable to" the highly contaminated LabDiet 5002. It undoubtedly contained a high level of spurious GMOs, with effects on both treated and control animals from these contaminants likely to be comparable to those from the tested GM maize.

Séralini et al. used the A04 diet, which has only $0.3 \%$ GM soy and (according to Fig. 2 of Mesnage et al. [117] ) no glyphosate or AMPA: it is one of the least contaminated diets. In addition, the Séralini group tested the A04 diet used in their study for GMOs and found none. They also tested their maize for 540 pesticides, including glyphosate, and none was found to be over standard limits [120].

As shown by Séralini et al., consumption of either the GM trait in NK603 or Roundup resulted in progressive worsening of many health parameters and higher frequencies of early mortality and tumour formation. Therefore the presence of GM traits and Roundup residues in the feed of Monsanto's control rats very likely had an equalizing effect between treated animals and controls. Hence, all results of the Monsanto study [7] must be considered unreliable.

Mesnage et al. [117] pointed out that contaminants in laboratory rodent feeds may be responsible for the high rates of "spontaneous" diseases, including tumour formation, in rodents used for feeding trials. It is notable that only one of the Séralini et al. control males developed tumours, while females did so only at about half the rate of treated animals.

The discovery that most standard laboratory feeds are contaminated with biologically important substances has the corollary that all past feeding trials on rodents need to be re-examined for the type and extent of contamination.

\subsection{Corroborative studies}

(1) In March 2015 the IARC published a monograph [121] concluding that there is "sufficient evidence" of carcinogenicity of glyphosate in experimental animals, as well as "limited evidence of carcinogenicity in humans for non-Hodgkin lymphoma". The study has been vigorously denounced by Monsanto and other groups, pointing to evidence of no harm-albeit that these are based largely or exclusively on industry studies, including unpublished ones (the IARC panel was restricted to assessing only publicly available studies published in the scientific literature or as government reports). Monsanto's protestations are hypocritical, as their own unpublished studies from as far back as the early 1980s, obtained under the Freedom of Information Act, found malignant tumours in rats and mice given glyphosate [122]. In 2017, it emerged from confidential electronic correspondence of Monsanto, which was unsealed during litigation in California, that the company had hired Intertek Scientific \& Regulatory Consultancy [123] to write a "Critical Review by an Expert Panel" on glyphosate to counter the conclusion of IARC, and had intervened heavily in the production of that review [124].

(2) Séralini et al. [6, 107] had saved the organs of the rats in their experiment. The livers of female rats given the lowest amount, $0.1 \mathrm{ppb}$ or $50 \mathrm{ng} / \mathrm{L}$, of Roundup in their drinking water, as well as livers of the controls, were used in a new study [125] combining the proteomic and metabolomic profiles of the livers. The latter were "clearly reflective of features of non-alcoholic fatty liver disease (NAFLD) and its progression to non-alcoholic steatohepatosis". These results may have implications for human health. In the United States, a large proportion of the population has excessive liver fat.

(3) A review [126] of the published literature and regulatory reports found that glyphosate and its formulations as herbicide could cause teratogenic. tumorigenic and hepatorenal effects, which could be explained by endocrine disruption and oxidative stress. Some of the effects were found in the range of the recommended acceptable daily intake. Adjuvants in glyphosate-based herbicides may be more toxic than glyphosate itself and also increase the toxicity of glyphosate. Yet adjuvants are not always declared, and regulating bodies test only the effects of glyphosate alone. In a separate paper, Séralini stated that "The declared active principles often appear to be by far the least toxic compounds after water in formulations" [127].

(4) In-depth molecular profiling [128] of the same GM maize, NK603, that was studied by the Séralini team in their 2012/2014 paper revealed that the genetic 
transformation process altered the proteomic and metabolomic profiles of the maize and caused marked metabolic changes. Thus NK603 is not "substantially equivalent" to its isogenic non-GM variety, although "substantial equivalence" was the criterion on which the maize had gained regulatory approval.

(5) Roundup was given to adult male rats in acute exposure $(0.5 \%)$ during 8 days [129], resulting in changes of expression of aromatase in the testis and of nuclear markers in spermatozoa.

\section{THE MONSANTO PAPERS}

Monsanto has engaged in covert operations to deceive the public and regulators about the damaging effects of Roundup [130].

The judge overseeing litigation in California concerning claims that Monsanto's Roundup herbicide had caused non-Hodgkin's lymphoma in the plaintiffs, while its health risks had not been disclosed, unsealed a large number of documents including memos and e-mails deposited by Monsanto Company. These documents, sometimes called the "Monsanto Papers', were published on 2 August 2017 and reveal the extent of the company's involvement in the retraction of the Séralini et al. paper.

A series of e-mails [131] was exchanged at Monsanto Company on 26 September 2012 (one week after online publication of the Séralini et al. paper) revealing the company's campaign to encourage scientists to write condemnatory Letters to the Editor, and the Editor-in-Chief's encouragement of the campaign. David Saltmiras, Toxicology Manager, Regulatory Product Safety Center, wrote: "Wally Hayes (FCT Editor-in-Chief) called me this morning in response to my voice mail yesterday. He expressed concern that to date he has only received links to blogs, web postings, media releases, etc. and no formal Letters to the Editor. $\mathrm{He}$ genuinely wants to provide scientific leadership at FCT based on reliable information; scientific responses from credible sources submitted as Letters to the Editor are critical. Therefore, he urgently needs rational, objective and authoritative formal letters to the Editor. He said either electronic submission to FCT or direct email to him are acceptable-I suggest both." A few e-mails later, Eric Sachs wrote: "I remain adamant that Monsanto must not be put in the position of providing the critical analysis that leads the editors to retract the paper." William Heydens replied: "This makes no sense to me at all. We have defended our science every step of the way since our 1 st encounter with him. Why are we silent now? That fact remains that the external sector has not given us what we need, and the editor is telling us it is the 11 th hour and he has nothing to work with. He directly told us
(Monsanto) to give him something to work with or else his hands are tied and we will deal with the consequences." Eric Sachs responded: "I am not challenging that Monsanto should defend our science ... we absolutely should and have. There is a difference between defending science and participating in a formal process to retract a publication that challenges the safety of our products. We should not provide ammunition for Séralini, GM critics and the media to charge that Monsanto used its might to get this paper retracted. The information that we provided clearly establishes the deficiencies in the study as reported and makes a strong case that the paper should not have passed peer review".

Then, on 9 October 2012, Daniel Goldstein wrote in an e-mail [132] to a large group: "1) Retraction-both Dan Jenkins (US Government Affairs) and Harvey Glick made a strong case for withdrawal of the paper if at all possible, both on the same basis - that publication will elevate the status of the paper, bring other papers in the journal into question, and allow Séralini much more freedom to operate."

Of special concern is the newly revealed conflict of interest of the Editor-in-Chief, who signed on 7 September 2012 [133] a "Consulting Agreement dated August 21, 2012, between Prof. A. Wallace Hayes and Monsanto Company (the 'Agreement'); Project Title: Latin America South Toxicology Expert Panel initial meeting preparation and participation." It includes the following excerpt:

"This letter is issued pursuant to the Agreement and authorizes you to provide the following consulting services beginning September 7, 2012 for the agreed upon fee of $\$ 400.00$ per hour, not to exceed $\$ 3,200$ per day and a total of $\$ 16,000$ : [Assist in establishment of an expert network of toxicologists, epidemiologists, and other scientists in South America and participate on the initial meeting held within the region. Preparation and delivery of a seminar addressing relevant regional issues pertaining to glyphosate toxicology is a key deliverable for the inaugural meeting in 2013.]"

According to the New York Times [134], "Mr. Hayes said in an interview that he had not been under contract with Monsanto at the time of the retraction and was paid only after he left the journal. 'Monsanto played no role whatsoever in the decision that was made to retract,' he said. 'It was based on input that I got from some very well-respected people, and also my own evaluation.' "

Another court document states: Monsanto executive William Heydens "appears to have spent a great deal of his career ghostwriting 'science' papers to protect Roundup, those efforts rivalled in time and scope only by his colleague David Saltmiras. This has been an important subject of this litigation so far, and is central to general 
causation; Monsanto relies heavily upon the scientific literature and governmental approvals of glyphosate for its general causation defense; as the Court is aware, however, the discovery process is yielding substantial evidence that Monsanto is often the puppetmaster behind scientific articles that are positive for the company, as well as US EPA deliberations and reports" [135].

\section{DISCUSSION}

The fate suffered by the paper of Séralini et al. [6] is, unfortunately, not limited to this one case. Other scientists reporting studies finding deleterious consequences from a GM crop have found their reports rejected for publication, while other papers reaching a favourable conclusion about GM crops have been accepted. Papers deemed by the GM industry to be threatening have brought vicious verbal attacks upon the authors. In the case of the Séralini et al. paper, the conflicted Editor-in-Chief assisted Monsanto in bringing about the paper's defamation and retraction.

The importance of the retraction lies in the consequences that would arise for Monsanto Company if the paper were to gain wide acceptance. Monsanto is a GM seed developer and markets both GM seeds and the herbicide Roundup, to which some $80 \%$ of all GM crops are tolerant. Any demonstration that these products cause serious health problems is therefore alarming for the company. Demonstration of the toxicity of Roundup or of harm from the consumption of GM crops would probably cause the demise of Monsanto, at least in its present form, since it has become almost solely dependent on this line of business. This, however, does not justify the secret manoeuvrings by Monsanto that brought about the retraction of the Séralini et al. paper.

The deafness of Séralini's critics to the repeated remonstrance that the study was not about carcinogenicity but about toxicity is explainable in terms of Monsanto's overwhelming need to get a retraction. When even a second peer review of the 2012 paper could find no legitimate fault, an illegitimate but scientificsounding excuse had to be put forward: calling the study a carcinogenicity study that was badly designed, with too few animals and a wrong strain of animal that is prone to tumours anyway. With these "concerns", the paper was then retracted solely on the grounds of "inconclusiveness", a new concept in scientific publishing.

The losers in this sordid game of profits-above-all are the degraded soils that are drenched in pesticides, grievously harming beneficial microörganisms in the rhizosphere; crops that are laden with toxic residues; farms that can no longer control resistant weeds and insects; wildlife that is being decimated, farm animals that become ill; and, no doubt, the public whose food has lowered nutritional value and raised levels of toxic chemicals. The rise in chronic illnesses in the USA paralleling the introduction of unlabeled GM foods there [136] may not be a coincidence, especially as the health of thousands of individual Americans has improved after removing or reducing the GM content of their diet [137].

\section{CONCLUSION}

The story of this paper demonstrates clearly how deeply the influence of corrupt corporations has penetrated into what should be the untouchable scientific integrity of editors, publishers, regulators, learned societies, governments and even the corporations themselves. Science today, at least in the United Kingdom, is increasingly aimed not at discovering how the world works, and for the betterment of mankind, but at what can be developed and marketed as quickly as possible for the betterment of company profits and the national economy. Although the Séralini team acknowledge that their results are not definitive they are sufficiently strong to convey a warning message that the crop and herbicide investigated may pose a serious threat to health.

An important revelation in 2015 was that most standard diets used in feeding trials of GM products are contaminated not only with pesticides but also with various GMOs [117]. Séralini's team tested all their feed to ensure that it was free of these contaminants. The fact that most laboratory diets fed to rodents are contaminated with substances that can affect the results of a feeding trial means that all papers testing the safety of GM crops need to be reëxamined for contamination of the feed used; their results must be discounted if contamination is found. This would include Monsanto's paper [7] on which the safety of GM maize NK603 was largely based to obtain regulatory approval in the EU.

Another decisive factor in safety testing is the duration of a feeding trial. Séralini et al. found that significant damage to health is only incipient at the end of 90 days, which is the duration favoured by industry. Longterm testing, comparable to the lifetime of an animal, is needed to show worsening effects over time. Studies terminating at 90 days are insufficient to demonstrate safety.

Corruption of science is not limited to the GM industry: it exists in the medical, pharmaceutical and cellphone industries, as well as others. Methods that trace back to private companies, and sometimes involving high government officials, have been used to obtain favours in the Spanish health sector [138]. Corporate profits and short-term prospects for the national economy and for corrupt individuals have been taking precedence over public welfare. 
The integrity of science has been seriously compromised. Public and environmental health are already affected by corrupt practices of organizations and individuals. Severe sanctions need to be put in place. It is difficult to guard against covert machinations to subvert science, like those of Monsanto and the colluding journal editor of the Séralini et al. paper. Ultimately, restoring integrity to science will require restoration of the personal integrity of the faulty individuals involved in research or its deployment into society.

\section{REFERENCES}

1. Hilbeck, A. et al. No scientific consensus on GM safety. Environ. Sci. Europe 27 (2015) 4.

2. Kvakkestad, V., Gillund, F., Kjølberg, K.A. \& Vatn, A. Scientists' perspectives on the deliberate release of GM crops. Environ. Values 16 (2007) 79-104.

3. Diels, J., Cunha, M., Manaia, C., Sabugosa-Madeira, B. \& Silva, M. Association of financial or professional conflict of interest to research outcomes on health risks or nutritional assessment studies of genetically modified products. Food Policy 36 (2011) 197-203.

4. Rowell, A. Don't Worry [It's Safe to Eat], chs 5 \& 6. London: Earthscan Publications (2003).

5. Rowell, A. Don't Worry [It's Safe to Eat], ch. 8. London: Earthscan Publications (2003).

6. Séralini, G.-E., Clair, E., Mesnage, R., Gress, S., Defarge, N., Malatesta, M., Hennequin, D. \& Spiroux de Vendômois, J. Long term toxicity of a Roundup herbicide and a Roundup-tolerant genetically modified maize. Food Chem. Toxicol. 50 (2012) 4221-4231.

7. Hammond, B., Dudek, R., Lemen, J. \& Nemeth, N. Results of a 13 week safety assurance study with rats fed grain from glyphosate tolerant corn. Food Chem. Toxicol. 42 (2004) 1003-1014.

8. Fagan, J., Antoniou, M. \& Robinson, C. GMO Myths and Truths, 2nd edn, Section 3.2. London: Earth Open Source (2012).

9. Fagan, J., Traavik, T. \& Bøhn, T. The Séralini affair: degeneration of science to re-science? Environ. Sci. Europe 27 (2015) $19-27$.

10. Resnick, D.B. Retracting inconclusive research: Lessons from the Séralini GM maize feeding study. J. Agric. Environ. Ethics 28(2015) 621-633.

11. Engdahl, F.W. Ratted out: Scientific journal bows to Monsanto over anti-GMO study. RT (2013): https://www.rt.com/op-edge/ monsanto-gmo-studies-reports-588/Shorter version: Scientific journal retracts study exposing GM cancer risk. The Ecologist h t t p : / / w w w. the e c o log i s t. org/N e w s/new s_a naly s i s/21854 $42 /$ scientific_journal_retracts_study_exposing_gm_cancer_risk.html

12. Novotny, E. Scientific Publication in Peril: the Séralini Affair. Scientists for Global Responsibility: http://www.sgr.org.uk/resources/ scientific-publication-peril-seralini-affair

13. Private communication from Robin Mesnage (April 2016).

14. Robinson, C., Antoniou, M. \& Fagan, J. GMO Myths and Truths, 3rd edn, pp. 33-35. London: Earth Open Source (2015).

15. Waltz, E. Under wraps. Nature Biotechnol. 27 (2009) 880-882.

16. Mesnage, R., Bernay, B. \& Séralini, G.-E. Ethoxylated adjuvants of glyphosate-based herbicides are active principles of human cell toxicity. Toxicology 313 (2013) 122-128.

17. Mesnage, R., Defarge, N., Spiroux de Vendômois, J. \& Séralini, G.-E. Major pesticides are more toxic to human cells than their declared active principles. BioMed Research International (2014) 179691.

18. Brix, A.E., Nyska, A., Haseman, J.K., Sells, D.M., Jokinen, M.P. \& Walker, N.J. Incidences of selected lesions in control female Harlan Sprague Dawley rats from two-year studies performed by the National Toxicology Program. Toxicol. Pathol. 33 (2005) 477-483.

19. Chandra, M., Riley, M.G. \& Johnson, D.E. Spontaneous neoplasms in aged Sprague Dawley rats. Arch. Toxicol. 66 (1992) 496-502.

20. Science Media Centre (20 September 2012): http://www.sciencemediacentre.co.nz/2012/09/20/study-on-cancer-and-gmmaize-experts-respond/

21. Science Media Centre: http://www.sciencemediacentre.org

22. How independent is the Science Media Centre and its experts? (2012): http://www.gmwatch.org/component/content/article/14224

23. Letters to the Editor of Food Chem. Toxicol., too numerous to list individually: see http://www.sciencedirect.com/science/ article/pii/S0278691512005637 for links to them.

24. Sakamoto, Y., Tada, Y., Fukumori, N., Tayama, K., Ando, H., Takahashi, H., Kubo, Y., Nagasawa, A., Yano, N., Yuzawa, K. \& Ogata, A. A 104-week feeding study of genetically modified soybeans in F344 rats. Shokuhin Eiseigaku Zasshi (J. Food Hyg. Soc.) 49 (2008) 272-282 [in Japanese].

25. Medscape Oncologie and GMO Séralini. Interview with Dr Joël Spiroux de Vendômois. (3 December 2012): http:// www.gmoseralini.org/medscape-oncologie-dr-spiroux-co-author-of-the-shocking-study-responds-to-criticisms/

26. Snell, C., Bernheim, A., Bergé, J.-B., Kuntz, M., Pascal, G., Paris, A. \& Ricroch, A.E. Assessment of the health impact of GM plant diets in long-term and multigenerational animal feeding trials: A literature review. Food Chem. Toxicol. 50 (2012) 1134-1148. 
27. Jacquemart, F. The safety of GMO: studies are based on non scientific conclusions. Inf' OGM, le journal no 128 (May/June 2014): https://www.infogm.org/5667-Safety-of-GMO-studies-are-based-on-non-scientific-conclusions?lang=fr

28. Monsanto Responds to French Rat Study (Séralini et al., 2012) (21 September 2012): http://www.monsantoglobal.com/global/ au/newsviews/Pages/monsanto-responds-to-french-rat-study.aspx

29. Samsel, A. \& Seneff, S. Glyphosate, pathways to modern diseases IV: cancer and related pathologies. J. Biol. Phys. Chem. 15 (2015) 121-159.

30. Avis des Académies nationales d'Agriculture, de Médecine, de Pharmacie, des Sciences, des Technologies, et Vétérinaire sur la publication récente de G.E. Séralini et al. sur la toxicité d'un OGM (October 2012): http://www.academiesciences.fr/fr/Rapports-ouvrages-avis-et-recommandations-de-1-Academie/avis-des-academies-nationales-d-agriculturede-medecine-de-pharmacie-des-sciences-des-technologies-et-veterinaire-sur-la-publication-recente-de.html

31. Arjó, G., Portero, M., Piñol, C, Viñas, J., Matias-Guiu, X., Capell, T.,Bartholomaeus. A., Parrott, W. \& Christou, P. Plurality of opinion, scientific discourse and pseudoscience: an in depth analysis of the Séralini et al. study claiming that RoundupTM Ready corn or the herbicide RoundupTM cause cancer in rats. Transgenic Res. 22 (2013) 255-267.

32. A scientific analysis of the rat study conducted by Gilles-Eric Séralini et al.: http://www.vib.be/en/news/Documents/ 20121008_EN_Analyse\%20rattenstudie\%20Séralini\%20et\%20al.pdf

33. Press Kit, A presentation of ANSES's Opinion following its analysis of the study by Séralini et al. (2012) (22 October 2012): https://www.anses.fr/en/system/files/PRES2012CPA20EN.pdf

34. Séralini's team and CRIIGEN win two court cases about their research on toxicity of GMOs and pesticides (27 November 2015): http://gmwatch.org/news/latest-news/16557

35. Séralini wins defamation case against French news magazine Marianne (11 September 2016): http://www.gmwatch.org/news/ latest-news/17208-seralini-wins-defamation-case-against-french-news-magazine-marianne

36. Lacoste, S. A JUST PAYBACK!, Rebelle-Santé no 153. (March 2013).

37. EFSA publishes initial review on GM maize and herbicide study (4 October 2012): https://www.efsa.europa.eu/en/press/news/ 121004

38. Final review of the Séralini et al. (2012) publication on a 2-year rodent feeding study with glyphosate formulations and GM maize NK603 as published online on 19 September 2012 in Food and Chemical Toxicology (28 November 2012). EFSA J. 10 (2012) 2986-2995 (https://www.efsa.europa.eu/en/efsajournal/pub/2986).

39. Then, C. The European Food Safety Authority: Using double standards when assessing feeding studies. Testbiotech (20 October 2012): http://www.testbiotech.de/sites/default/files/the\%20double\%20standards\%20of\%20EFSA_0.pdf

40. Robinson, C., Holland, N., Leloup, D.\& Muilerman, H. Conflicts of interest at the European Food Safety Authority erode public confidence. J. Epidemiol. Community Health 67 (2013) 717-720.

41. A Playground of the Biotech Industry? Need for reform at the European Food Safety Authority (November 2012): https:// www.testbiotech.org/sites/default/files/TBT\%20Background $\% 20$ on $\% 20$ EFSA_Conflict $\% 20$ of $\% 20$ Interests.pdf

42. International Life Sciences Institute (ILSI): https://www.ilsi.org

43. Holland, N., Robinson, C. \& Harbison, R. Conflicts on the menu-a decade of industry influence at the European Food Safety Authority. Corporate Europe Observatory and Earth Open Source (February 2012): http://www.corporateeurope.org/ publications/conflicts-menu

44. Lougheed, T. Policy: WHO/ILSI affiliation sustained. Environ. Health Perspectives 114 (2006) A521.

45. European Food Safety Authority (EFSA): https://www.efsa.europa.eu

46. Robinson, C., Antoniou, M. \& Fagan, J. GMO Myths and Truths, 3rd edn, pp. 18-19. London: Earth Open Source (2015).

47. Holland, N., Robinson, C. \& Harbison, R. Conflicts on the menu-a decade of industry influence at the European Food Safety Authority. Corporate Europe Observatory and Earth Open Source, p. 10 (February 2012): http://www.corporateeurope.org/ publications/conflicts-menu

48. Smith, J.M. Seeds of Deception: Exposing Industry and Government Lies about the Safety of the Genetically Engineered Foods You're Eating, 7th printing, pp. 72-75. Fairfield, Iowa: Yes! Books (2003).

49. Smith, J.M. Genetic Roulette: The Documented Health Risks of Genetically Engineered Foods, especially Part 3. Fairfield, Iowa: Yes! Books (2003).

50. EFSA: a playing field for biotech industry (November 2010): http://www.testbiotech.org/node/426

51. Independence of EFSA's GMO risk assessment challenged: Complaint filed with the EU Ombudsman (21 March 2012): http:// www.testbiotech.org/en/node/638k. Response from Executive Director of EFSA: https://www.testbiotech.org/sites/default/ files/0622-2012-ANA-E2012-159705_0.pdf

52. New appointments in Science Strategy and Coordination Directorate (16 May 2013): http://www.efsa.europa.eu/en/ press/news/130516c.htm

53. Independence of EFSA's GMO risk assessment challenged (March 2012): https://corporateeurope.org/pressreleases/2012/ independence-efsas-gmo-risk-assessment-challenged

54. Leading European Food Safety Authority Staff Member Moves into Industry (November 2009): https://www.testbiotech.org/ en/node $/ 260$

55. Suzy Renckens (March 2013): http://powerbase.info/index.php/Suzy_Renckens 
56. OGM: l'agence européenne aux double casquettes (6 October 2012): http://bit.ly/R4n65a

57. Pusztai hitman oversaw EFSA’s demolition of Séralini (October 2012): http://www.gmwatch.org/news/14296

58. Second report on discharge in respect of the implementation of the budget of the European Food Safety Authority for the financial year 2010 (document A7-0299/2012) (October 2012): http://www.europarl.europa.eu/sides/getDoc.do?pubRef=-// $\mathrm{EP} / / \mathrm{TEXT}+\mathrm{REPORT}+\mathrm{A} 7-2012-0299+0+\mathrm{DOC}+\mathrm{XML}+\mathrm{V} 0 / / \mathrm{EN} \&$ language $=\mathrm{en}$

59. European Food Safety Authority mishandled a major revolving doors case with biotechnology company Syngenta (29 May 2013): https://corporateeurope.org/pressreleases/2013/eu-ombudsman-efsa-fails-conflict-interests-p

60. MOTIONFORAEUROPEAN PARLIAMENTRESOLUTION, Follow-up of 2011 discharge (document A7-0219/2014, under part 3) (21 March 2014): http://www.europarl.europa.eu/sides/getDoc.do?type=REPORT\&reference=A7-2014-0219\&language=EN

61. The European Parliament demands stricter regulation of conflicts of interest at EU's food safety authority (3 April 2014): https://corporateeurope.org/pressreleases/2014/04/european-parliament-demands-stricter-regulation-conflicts-interesteus-food

62. Corporate Europe Observatory and Earth Open Source, p. 30 (February 2012): http://www.corporateeurope.org/publications/ conflicts-menu

63. Waldman, P., Mulvaney, L., Stecker, T. \& Rosenblatt, J. Does the World's Top Weed Killer Cause Cancer? Trump's EPA Will Decide. Bloomberg Business Week (13 July 2017): https://www.bloomberg.com/news/features/2017-07-13/does-the-world-stop-weed-killer-cause-cancer-trump-s-epa-will-decide

64. Clausing, P. (2017). Glyphosate and cancer: Authorities systematically breach regulations: How industry strategized (and regulators colluded) in an attempt to save the world's most widely used herbicide from a ban. GLOBAL 2000 (Friends of the Earth Austria): https://www.global2000.at/sites/global/files/Glyphosate_authorities_breach_regulations.pdf

65. Considerations on the applicability of OECD TG 453 to whole food/feed testing. EFSA J. 11 (2013) 3347-3364.

66. 452: Guidelines for the Testing of Chemicals - Chronic ToxicityStudies. OECD (2009).

67. GMO Risk Assessment and Communication of Evidence (GRACE). Conclusions and recommendations on animal feeding trials and alternative approaches and on the use of systematic reviews and evidence maps for GMO impact assessment: http:/ /www.grace-fp7.eu/sites/default/files/GRACE_Conclusions\%20\&Recommendations.pdf

68. Suspected manipulation in the outcome of EU research project (7 November 2014): https://www.testbiotech.org/en/node/1110

69. Bauer-Panskus, A. \& Then, C. (DIS-)GRACE: Risk assessment on the leash of the biotech industry (22 April 2013): https:// www.testbiotech.org/sites/default/files/TBT\%20Background\%20GRACE_final_0.pdf

70. A presentation of ANSES's Opinion following its analysis of the study by Séralini et al. (2012) "Long term toxicity of a ROUNDUP herbicide and a ROUNDUP-tolerant genetically-modified maize” (22 October 2012): https://www.anses.fr/en/ system/files/PRES2012CPA20EN.pdf

71. Factor GMO. http://factorgmo.com

72. Séralini, G.-E., Mesnage, R., Defarge, N., Gress, S., Hennequin, D., Clair, E., Malatesta, M. \& Spiroux de Vendômois, J. Answers to critics: Why there is a long term toxicity due to a Roundup-tolerant genetically modified maize and to a Roundup herbicide. Food Chem. Toxicol. 53 (2013) 476-483.

73. ENSSER Comments on Séralini et al. 2012 (5 October 2012): https://ensser.org/topics/democratising-science-and-descisionmaking/ensser-comments-on-the-retraction-of-the-seralini-et-al-2012-study/

74. Heinemann, J. Food and chemical toxicology (Letter to the Editor). Food Chem. Toxicol. 53 (2013) 442.

75. Bardocz, S. et al. Séralini and Science: An Open Letter. Independent Science News (2 October 2012): https:// www.independentsciencenews.org/health/seralini-and-science-nk603-rat-study-roundup/

76. [140 French scientists]. Science et conscience. Le Monde (14 November 2012).

77. Robin, M.-M. Le procès Séralini/Fellous et les conflits d'intérêt de l'AFBV (October 2012): http://robin.blog.arte.tv/2010/12/06/ le-proces-seralini-fellous-et-les-conflits-dinteret-de-lafbv/

78. What's behind the science academies' attack on Séralini? (28 October 2012): http://www.gmwatch.org/latest-listing/51-2012/14367

79. Guyon, C. Rebelle-Santé no 153 (March 2013).

80. Saunders, P. Excess Cancers and Deaths with GM Feed: the Stats Stand Up. Science in Society Archive (16 October 2012): http://www.i-sis.org.uk/Excess_cancers_and_deaths_from_GM_feed_stats_stand_up.php

81. Comment on Séralini findings and stats by former government analyst (1 October 2012): http://www.gmwatch.org/news/ archive/2012/14249-note-the-french-agency-for-food-environmental-and-occupational-health-safety-anses-will-report-onseralinis-study-on-gm-nk603-maize-which-found-that-the-maize-as-well-as-tiny-amounts-of-the-roundup-herbicide-it-isgrown-with-caused-tumours-premat

82. Loening, U. Comments on Séralini et al. (2012) and on the criticisms of that paper (27 October 2012): http://www.gmwatch.org/ news/archive/2012/14436-comments-on-seralini-et-al-and-on-the-criticisms

83. Food and Chemical Toxicology journal statement (2013): http://cdn.elsevier.com/promis_misc/ food_and_chemical_toxicology_homepage_statement.pdf

84. Hayes, A.W. Letter to G.-E. Séralini (19 November 2013): http://www.gmwatch.org/files/Letter_AWHayes_GES.pdf

85. Retraction notice to "Long term toxicity of a Roundup herbicide and a Roundup-tolerant genetically modified maize" [Food Chem. Toxicol. 50 (2012) 4221-4231]. Food Chem. Toxicol. 63 (2014) 244. 
86. Article withdrawal: Elsevier's policy: https://www.elsevier.com/about/company-information/policies/article-withdrawal

87. Committee On Publication Ethics (COPE). Retraction Guidelines: http://publicationethics.org/files/retraction\%20guidelines_0.pdf

88. Hayes, A. W. Response to Letters to the Editors. Food Chem. Toxicol. (10 December 2013): https://www.elsevier.com/about/pressreleases/research-and-journals/food-and-chemical-toxicology-editor-in-chief,-a.-wallace-hayes,-publishes-response-toletters-to-the-editors

89. Economic interests quashing scientific controversy? (29 November 2013): http://www.testbiotech.de/en/node/972

90. Spherix (2009): https://www.sec.gov/Archives/edgar/data/12239/000114420409022374/v147247_ex99-1.htm

91. Introduction to Spherix Consulting (August 2016): http://docplayer.net/28825247-Introduction-to-spherix-consulting.html

92. Independent expert: Richard E. Goodman (23 August 2013): https://gmoanswers.com/experts/richard-e-goodman

93. Scientists for Global Responsibility open letter on pro-GM bias at academic journal (1 October 2013): http://www.sgr.org.uk/ resources/open-letter-pro-gm-bias-academic-journal

94. Foucart, S. La discrète influence de Monsanto. Le Monde (11 July 2016).

95. Robinson, C. Emails reveal role of Monsanto in Séralini study retraction (20 July 2016): http://gmwatch.org/news/latestnews/17121-emails-reveal-role-of-monsanto-in-Séralini-study-retraction

96. Response by Prof GE Séralini and colleagues to A. Wallace Hayes, editor of Food and Chemical Toxicology (28 November 2013): http://www.gmwatch.org/en/news/archive/2013/15188-prof-Séralini-responds-to-fct

97. Séralini releases statement on retraction and correspondence with ethics watchdog (4 March 2014 ): https:// www.gmoseralini.org/seralini-releases-statement-on-retraction-and-correspondence-with-ethics-watchdog/

98. Séralini, G.-E., Mesnage, R., Defarge, N. \& Spiroux de Vendômois, J. Conclusiveness of toxicity data and double standards. Food Chem. Toxicol. 69 (2014) 357-359.

99. Zhang, M., Zhuo, Q., Tian, Y., Piao, J. \& Yang, X. Long-term toxicity study on transgenic rice with Cry $1 A c$ and $s c k$ genes. Food Chem. Toxicol. 63 (2014) 76-83.

100. Spiroux de Vendômois, J., Roullier, F., Cellier, D. \& Séralini, G.E. A comparison of the effects of three GM corn varieties on mammalian health. Intl J. Biol. Sci. 5 (2009) 706-726.

101.Loening, U. A challenge to scientific integrity: a critique of the critics of the GMO rat study conducted by Gilles-Eric Séralini et al. (2012). Environ. Sci. Eur. 27 (2015) 13.

102. ENSSER Comments on the Retraction of the Séralini et al. 2012 Study (29 November 2013): http://www.ensser.org/ democratising-science-decision-making/ensser-comments-on-the-retraction-of-the-Séralini-et-al-2012-study/

103. Meyer, H. \& Hilbeck, A. Rat feeding studies with genetically modified maize - a comparative evaluation of applied methods and risk assessment standards. Environ. Sci. Eur. 25 (2013) 33.

104. Ho, M.-W. \& Saunders, P. Retracting Séralini Study Violates Science and Ethics. Science in Society Archive (4 December 2013): http://www.i-sis.org.uk/Retracting_Serallini_study_violates_science_and_ethics.php

105. Open Letter on Retraction and Pledge to Boycott Elsevier (4 December 2013): http://www.i-sis.org.uk/ Open_letter_to_FCT_and_Elsevier.php

106. Retraction of Séralini GMO study is attack on scientific integrity (2014): http://www.endsciencecensorship.org

107. Séralini, G.-E., Clair, E., Mesnage, R., Gress, S., Defarge, N., Malatesta, M., Hennequin, D. \& Spiroux de Vendômois, J. Republished study: long term toxicity of a Roundup herbicide and a Roundup-tolerant genetically modified maize. Environ. Sci. Europe 26 (2014) 14-30.

108. Séralini, G.-E., Mesnage, R., Defarge, N. \& Spiroux de Vendômois, J. Conflicts of interests, confidentiality and censorship in health risk assessment: the example of an herbicide and a GMO. Environ. Sci. Europe 26 (2014) 13-18.

109. Diels, J., Cunha, M., Manaia, C., Sabugosa-Madeira, B. \& Silva, M. Association of financial or professional conflict of interest to research outcomes on health risks or nutritional assessment studies of genetically modified products. Food Policy $\mathbf{3 6}$ (2011) 197-203.

110. Mezzomo, B.P., Miranda-Vilela, A.L., de Souza Freire, I., Barbosa, L.C., Portilho, F.A., Lacava, Z.G. \& Grisolia, C.K. WITHDRAWN: Effects of oral administration of Bacillus thuringiensis as spore-crystal strains Cry1Aa, Cry1Ab, Cry1Ac or Cry2Aa on hematologic and genotoxic endpoints of Swiss albino mice. Food Chem. Toxicol (2012) (https:// www.ncbi.nlm.nih.gov/pubmed/23146696).

111. Mezzomo, B.P., Miranda-Vilela, A.L., de Souza Freire, I., Barbosa, L.C., Portilho, F.A., Lacava, Z.G. \& Grisolia, C.K. Hematotoxicity of Bacillus thuringiensis as spore-crystal strains Cry1Aa, Cry1Ab, Cry1Ac or Cry2Aa in Swiss albino mice. J. Hematol. Thromboembolic Diseases 1 (2013) 104.

112. Holderbaum, D.F., Cuhra, M., Wickson, F., Orth, A.I., Nodari, R.O. \& Bøhn, T. Chronic responses of Daphnia magna under dietary exposure to leaves of a transgenic (event MON810) Bt-maize hybrid and its conventional near-isoline. J. Toxicol. Environ. Health A 78(2015) 993-1007.

113. Delaney, B., Appenzeller, L.M., Roper, J.M., Mukerji, P., Hoban, D. \& Sykes, G.P. Thirteen week rodent feeding study with processed fractions from herbicide tolerant (DP-Ø73496-4) canola. Food Chem Toxicol. 66 (2014) 173-184.

114. Mesnage, R., Defarge, N., Spiroux de Vendômois, J. \& Séralini, G.E. Letter to the Editor regarding "Delaney et al., 2014": Uncontrolled GMOs and their associated pesticides make the conclusions unreliable. Food Chem. Toxicol.72 (2014) 322. 
115. Australian Government, Dept. of Health, Office of the Gene Technology Regulator. Risk Assessment and Risk Management Plan for DIR 139: Commercial release of canola genetically modified for herbicide tolerance (March 2016): https://doczz.net/ doc/4389486/pdf-format-1380-kb — office-of-the-gene-technology-regu... [sic]

116. Delaney, B. Response to “Letter to the Editor regarding 'Delaney et al., 2014': uncontrolled GMOs and their associated pesticides make the conclusions unreliable". Food Chem. Toxicol. 72 (2014) 323.

117. Mesnage, R., Defarge, N., Roque, L.-M., Spiroux de Vendômois, J. \& Séralini, G.-E. Laboratory rodent diets contain toxic levels of environmental contaminants: implications for regulatory tests. PLoS ONE 10 (2015) e0128429.

118. CRIIGEN, Response by Delaney et al. on the contamination of their control diets (17 September 2014): http://www.criigen.org/ communique/89/display/-Response-by-Delaney-et-al-on-the-contamination-of-their-control-diets-

119. Private communication with E. Novotny (March 2015).

120. Private communication from R. Mesnage (16 April 2016).

121. International Agency for Research on Cancer. IARC Monographs Volume 112: Evaluation of five organophosphate insecticides and herbicides. (20 March 2015).

122. Samsel, A. \& Seneff, S. Glyphosate, pathways to modern diseases IV: Cancer and related pathologies. J. Biol. Phys. Chem. 15 (2015) 121-159.

123. Gillam, C. Monsanto says panel to review WHO findings on cancer link to herbicide [sic] (14 July 2015): https:// www.yahoo.com/news/monsanto-says-expert-panel-review-finding-cancer-herbicide-184600564.html

124. Baum, Hedlund, Aristei \& Goldman. Monsanto Papers nos 15-29(August 2017): https://www.baumhedlundlaw.com/toxic-tortlaw/monsanto-roundup-lawsuit/monsanto-secret-documents/

125. Mesnage, R., Renney, G., Séralini, G.-E., Ward, M. \& Antoniou, M.N. Multiomics reveal non-alcoholic fatty liver disease in rats following chronic exposure to an ultra-low dose of Roundup herbicide. Sci. Rep. 6 (2016) 39328.

126. Mesnage, R., Defarge, N., Spiroux de Vendômois, J. \& Séralini, G.E. Potential toxic effects of glyphosate and its commercial formulations below regulatory limits. Food Chem. Toxicol. 84 (2015) 133-153.

127. Séralini, G.-E. Why glyphosate is not the issue with Roundup. J. Biol. Phys. Chem. 15 (2015) 111-120.

128. Mesnage, R., Agapito-Tenfen, S.Z., Vilperte, V., Renney, G., Ward, M., Séralini, G.-E., Nodari, R.O. \& Antoniou, M.N. An integrated multi-omics analysis of the NK603 Roundup-tolerant GM maize reveals metabolism disturbances caused by the transformation process. Sci. Rep. 6 (2016) 37855.

129. Cassault-Meyer, E., Gress, E., Séralini, G.-E. \& Galeraud-Denis. I. An acute exposure to glyphosate-based herbicide alters aromatase levels in testis and sperm nuclear quality. Environ. Toxicol. Pharmacol. 38 (2014) 131-140.

130. Gillam, C. Whitewash: The Story of a Weed Killer, Cancer and the Corruption of Science. Washington DC: Island Press (2017).

131. Monsanto Papers | Secret Documents no 10. Baum Hedlund Aristei Goldman PC, Consumer Attorneys (1 August 2017): https:/www.baumhedlundlaw.com/toxic-tort-law/monsanto-roundup-lawsuit/monsanto-secret-documents-page-two/

132. Monsanto Papers | Secret Documents no 12. Baum Hedlund Aristei Goldman PC, Consumer Attorneys (1 August 2017): https://www.baumhedlundlaw.com/toxic-tort-law/monsanto-roundup-lawsuit/monsanto-secret-documents-page-two/

133. Monsanto Papers | Secret Documents no 7. Baum Hedlund Aristei Goldman PC, Consumer Attorneys (1 August 2017): https:/ /www.baumhedlundlaw.com/toxic-tort-law/monsanto-roundup-lawsuit/monsanto-secret-documents-page-two/

134. Hakim, D. Monsanto's Sway Over Research Is Seen in Disclosed Emails. New York Times (1 August 2017).

135. Case 3:16-md-02741-VC Document 226, Page 1, United States District Court, Northern District of California (6 April 2017): http://baumhedlundlaw.com/pdf/monsanto-documents/Plaintiffs-administrative-motion-to-file-under-seal.pdf

136. Swanson, N.L., Leu, A., Abrahamson, J. \& Wallet, B. Genetically engineered crops, glyphosate snd the deterioration of health in the United States of America. J. Org. Systems 9 (2014) 6-37.

137. Smith, J.M. Survey Reports Improved Health After Avoiding Genetically Modified Foods. “International Journal of Human Nutrition and Functional Medicine" (2017): http://docs.wixstatic.com/ugd/93e00d_fc0371813bf846fe808ebe81ab453de2.pdf

138. Hernández-Aguado, I. \& Chilet-Rosell, E. Pathways of undue influence in health policy-making: a main actor's perspective. J. Epidemiol. Community Health 72 (2018) 154-159. 